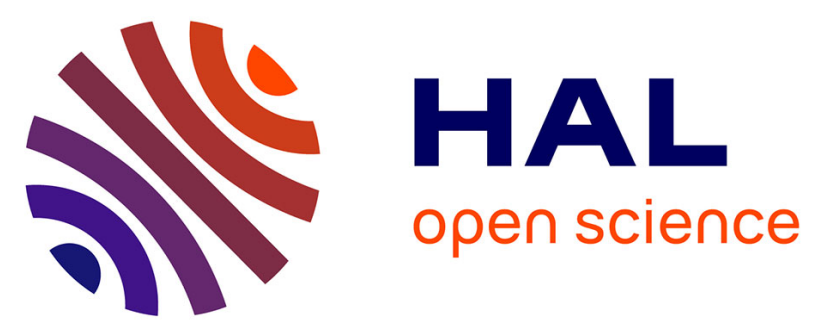

\title{
Geochemistry of the Martian meteorite ALH 84001, revisited
}

Jean-Alix J-A Barrat, Claire Bollinger

\section{To cite this version:}

Jean-Alix J-A Barrat, Claire Bollinger. Geochemistry of the Martian meteorite ALH 84001, revisited. Meteoritics and Planetary Science, 2010, 45 (4), pp.495-512. 10.1111/j.1945-5100.2010.01042.x . insu-00517865

\section{HAL Id: insu-00517865 https://hal-insu.archives-ouvertes.fr/insu-00517865}

Submitted on 26 Feb 2013

HAL is a multi-disciplinary open access archive for the deposit and dissemination of scientific research documents, whether they are published or not. The documents may come from teaching and research institutions in France or abroad, or from public or private research centers.
L'archive ouverte pluridisciplinaire HAL, est destinée au dépôt et à la diffusion de documents scientifiques de niveau recherche, publiés ou non, émanant des établissements d'enseignement et de recherche français ou étrangers, des laboratoires publics ou privés. 


\title{
Geochemistry of the Martian meteorite ALH 84001, revisited
}

\author{
Jean-Alix BARRAT ${ }^{*}$ and Claire BOLLINGER \\ Université Européenne de Bretagne and Université de Brest, CNRS UMR 6538 (Domaines Océaniques), I.U.E.M., \\ Place Nicolas Copernic, 29280 Plouzané Cedex, France \\ "Corresponding author. E-mail: barrat@univ-brest.fr
}

(Received 04 August 2009; revision accepted 26 December 2009)

\begin{abstract}
Major and trace element abundances were determined on powders prepared from four distinct chips from Allan Hills (ALH) 84001 to constrain the bulk rock composition, and to assess the trace element abundances of orthopyroxenes and phosphates. Our new determinations were used to evaluate the composition of the parental melt of this stone. An unrealistic light rare earth element (REE)-enriched parental melt is calculated from the composition of the orthopyroxene and relevant equilibrium partition coefficients. The involvement of a small amount of trapped melt and subsolidus reequilibrations between orthopyroxene and the interstitial phases can account for this discrepancy. A parental melt that displays a trace element pattern (REE, $\mathrm{Zr}$, and $\mathrm{Hf}$ ) that closely resembles enriched shergottites such as Zagami or Los Angeles is calculated if these effects are taken into account. These results suggest that some shergottitic melts were already erupted on Mars during the Noachian.
\end{abstract}

\section{INTRODUCTION}

In the absence of returned samples, the Martian meteorites provide a unique opportunity to constrain part of the reservoirs generated during the differentiation of the red planet. To date, about 50 Martian meteorites have been identified. Most of them are shergottites or nakhlites. These rocks are fragments of lava flows or intrusions, and formed from a variety of basaltic liquids. In addition, two cumulate lithologies have been recognized: the chassignites which are dunites, and Allan Hills (ALH) 84001, a unique orthopyroxenite (Mittlefehldt 1994).

ALH 84001 is the Martian meteorite which has been the center of, by far, the largest number of studies. As its Martian origin was recognized (Mittlefehldt 1994), it has been the focus of more than 300 publications or meeting abstracts. ALH 84001 is not only the sole Martian orthopyroxenite available on Earth, but it also displays unusual secondary carbonates that offer constraints on fluid-rocks interactions on Mars. Furthermore, this rock generated considerable interest when putative Martian fossils were discovered associated with the carbonates (McKay et al. 1996). This point has been vigorously discussed, but is not the only matter of discussion on this rock (the reader is referred to the Martian meteorite compendium by Meyer [2009], for an overview of the discussions about ALH 84001). Other issues include the formation of its secondary carbonates, the origin of its organic components, and more recently its crystallization age which is probably much younger than initially supposed (e.g., about $4.1 \mathrm{Ga}$ instead of $4.5 \mathrm{Ga}$; Bouvier et al. 2009; Jagoutz et al. 2009; Righter et al. 2009a).

The composition of the parental melts of Martian meteorites has often been a matter of debate. Some of these rocks, of course, display compositions very close to their parental lavas, as exemplified by the shergottites Queen Alexandra Range (QUE) 94201 (e.g., Kring et al. 2003), Yamato- (Y) 980459 (e.g., Usui et al. 2008), or Larkman Nunatak (LAR) 06319 (Basu Sarbadhikari et al. 2009). In other cases, the composition of the bulk rock is significantly shifted from that of the parental melt because of the accumulation of crystals (e.g., the lherzolitic shergottites or the nakhlites). Fortunately, this problem can be often overcome, sometimes by subtracting the compositions of the cumulus phases, by analyzing trapped melt inclusions (Johnson et al. 1991; Harvey and McSween 1992; Treiman 1993; Stockstill et al. 2005; Calvin and Rutherford 2008), or alternatively 


\section{ALH84001}

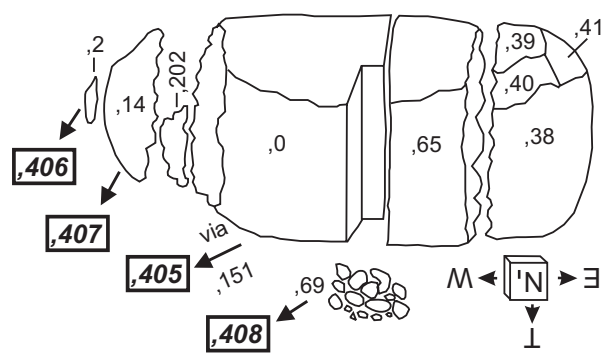

Fig. 1. Schematic drawing illustrating breaking and sawing of ALH 84001 and the location of the chips ,406 to ,408 used in this study (redrawn from Meyer 2009).

from partition coefficients and trace element abundances in zoned crystals (e.g., Wadhwa et al. 1994; Beck et al. 2006). Unlike the other Martian meteorites, the composition of the parental melt of ALH 84001 is difficult to constrain, because the major element composition of this meteorite is chiefly controlled by the composition of orthopyroxene, its predominant phase. Its thermal history has been particularly complex (e.g., Treiman 1995, 1998), and the compositions of the crystals have been homogenized by subsolidus processes. Thus, the trace element abundances of the parental melt cannot be directly deduced from equilibrium partition coefficients (Treiman 1996).

In this study, we present new major and trace element abundances obtained on four different chips of this unique meteorite, to evaluate the chemical heterogeneity of the stone, to discuss the trace element compositions of some of the phases (e.g., orthopyroxene, phosphates), and finally to obtain new constraints on the composition of its the parental melt.

\section{SAMPLES AND ANALYTICAL METHODS}

Four chips of ALH 84001 (splits ,405 to ,408) were obtained from the JSC curatorial facility. These fragments were taken from distinct carbonate-poor areas of the meteorite (Fig. 1), and this sampling provides a good picture of its heterogeneity.

Powders were prepared using a boron-carbide mortar and pestle. A fraction of each powder (weighing from 70 to $140 \mathrm{mg}$ ) was successively leached in $2 \mathrm{M} \mathrm{HCl}$ (leachate $\mathrm{L} 1,50{ }^{\circ} \mathrm{C}, 30 \mathrm{~min}$ ), and subsequently in $10 \mathrm{M}$ $\mathrm{HNO}_{3}\left(130{ }^{\circ} \mathrm{C}, 30 \mathrm{~min}\right)$. Residues (rinsed five times in ultrapure water) and unleached powders were completely dissolved using the procedure described by Barrat et al. (2008). The leaching procedure was drawn to obtain analyses from which trace element abundances of the orthopyroxenes and of the phosphates can be inferred.

Elemental abundances were determined using a high-resolution inductively coupled plasma-mass spectrometer Thermo Element 2 at Institut Universitaire Européen de la Mer (IUEM), Plouzané (Barrat et al. 2007, 2008). The results for the international standards PCC1 and BIR1 are given in Table 1. The standard data are in excellent agreement with previously published data sets confirming the very good quality of our calibration procedures. Based on standard measurements (see Table 1) and many sample duplicates, the $1 \sigma$ analytical uncertainties are in most cases better than $4 \%$, with the notable exceptions of the concentrations of $\mathrm{Be}(8 \%), \mathrm{Nb}(8 \%)$, Ta $(5 \%)$, and $\mathrm{Mo}$ $(10 \%)$. Results for ALH 84001 are given in Table 2.

\section{PETROGRAPHY}

ALH 84001 has been extensively described by numerous workers since 1992 (e.g., Berkley and Boynton 1992; Mittlefehldt 1994; Treiman 1995; Greenwood and McSween 2001). The reader is referred to the Martian meteorite compendium (Meyer 2009) for a detailed synthesis of the petrographic descriptions, to Mittlefehldt (1994) for the major element compositions of the main phases, and to Boctor et al. (2003) and Greenwood et al. (2003) for the major element compositions of the phosphates.

Briefly, ALH 84001 is a cataclastic orthopyroxenite. It contains minor amounts of chromite, feldspar-rich glass, phosphates (merrillite and apatite), clinopyroxene, olivine, pyrite, and carbonates. The carbonates in ALH 84001 have been extensively studied (Meyer 2009). They occur either as globules (so-called rosettes), or veins that display a distinctive chemical and textural zonation (sideritic or ankeritic carbonates in the cores, and rims of magnesite), and massive domains of ankeritic carbonate, variably intergrown with silicate glasses and minerals.

Because ALH 84001 is a coarse-grained rock (orthopyroxene crystals are often larger than $5 \mathrm{~mm}$ ), the proportions of the different phases are difficult to evaluate, especially for the minor phases. Meyer (2009) indicated the following proportions which are typical: about $97 \%$ orthopyroxene, $2 \%$ chromite, $1 \%$ feldsparrich glass, and $0.15 \%$ phosphates, all other phases are trace. ALH 84001 has been severely shocked and shock features are represented by fracturing and deformation in orthopyroxene and transformation of the feldspar to glass.

\section{RESULTS}

\section{Unleached Powders}

As shown by previous studies (Dreibus et al. 1994; Gleason et al. 1997; Kong et al. 1999; Warren et al. 1999), the major element compositions of chips are 
Table 1. Major and trace element abundances (oxides in $\mathrm{wt} \%$, traces elements in $\mu \mathrm{g} \mathrm{g}^{-1}$ ) for standards BIR-1 and PCC-1.

\begin{tabular}{|c|c|c|c|c|c|c|}
\hline & \multicolumn{3}{|l|}{ BIR-1 } & \multicolumn{3}{|l|}{ PCC-1 } \\
\hline & \multicolumn{2}{|l|}{ This study } & \multirow[b]{2}{*}{ Eggins et al. (1997) } & \multicolumn{2}{|l|}{ This study } & \multirow[b]{2}{*}{ Ionov et al. (2005) } \\
\hline & $n=3$ & RSD $\%$ & & $n=3$ & RSD $\%$ & \\
\hline $\mathrm{TiO}_{2}$ & 0.98 & 3.2 & 1.01 & & & \\
\hline $\mathrm{Al}_{2} \mathrm{O}_{3}$ & 15.21 & 3.9 & & & & \\
\hline $\mathrm{FeO}$ & 10.3 & 0.9 & & & & \\
\hline $\mathrm{MnO}$ & 0.17 & 1.5 & & & & \\
\hline $\mathrm{MgO}$ & 9.7 & 4.7 & & & & \\
\hline $\mathrm{CaO}$ & 13.64 & 5.9 & & & & \\
\hline $\mathrm{Na}_{2} \mathrm{O}$ & 1.7 & 2.6 & & & & \\
\hline $\mathrm{P}_{2} \mathrm{O}_{5}$ & 0.0208 & 4.9 & & 0.001 & 11.9 & \\
\hline $\mathrm{Li}$ & 3.3 & 2.5 & 3.32 & 1.17 & 3.5 & 0.93 \\
\hline $\mathrm{Be}$ & 0.084 & 7.5 & 0.116 & - & - & \\
\hline $\mathrm{K}$ & 180 & 4.1 & & 11 & 3.6 & \\
\hline $\mathrm{Sc}$ & 44.15 & 3.5 & 43.8 & 8.82 & 2.8 & 7.4 \\
\hline V & 322 & 2.0 & 322 & 30 & 2.3 & 34 \\
\hline $\mathrm{Cr}$ & 375 & 4.6 & 412 & & & \\
\hline $\mathrm{Mn}$ & 1275 & 1.5 & & 863 & 3.1 & \\
\hline Co & 50.8 & 2.0 & 53 & 105 & 5.1 & 108 \\
\hline $\mathrm{Ni}$ & 164 & 4.8 & 175 & 2029 & 5.0 & 2343 \\
\hline $\mathrm{Cu}$ & 106 & 7.0 & 113 & 6.27 & 2.6 & 6.5 \\
\hline $\mathrm{Zn}$ & 59.7 & 8.0 & 65 & 32.2 & 3.5 & \\
\hline $\mathrm{Ga}$ & 14.42 & 3.4 & 15.2 & 0.48 & 4.6 & \\
\hline $\mathrm{Rb}$ & 0.19 & 3.0 & 0.195 & 0.06 & 1.1 & 0.052 \\
\hline $\mathrm{Sr}$ & 106 & 2.2 & 106 & 0.38 & 0.6 & 0.36 \\
\hline Y & 16.94 & 0.4 & 16.2 & 0.09 & 4.1 & 0.077 \\
\hline $\mathrm{Zr}$ & 15.82 & 0.3 & 14.47 & 0.24 & 7.3 & 0.18 \\
\hline $\mathrm{Nb}$ & 0.67 & 7.0 & 0.56 & 0.03 & 21 & 0.016 \\
\hline Мo & 0.07 & 10.2 & 0.04 & 0.05 & 34 & \\
\hline $\mathrm{Ba}$ & 6.66 & 0.4 & 6.52 & 0.83 & 3.6 & 0.8 \\
\hline $\mathrm{La}$ & 0.627 & 1.2 & 0.604 & 0.0306 & 3.0 & 0.029 \\
\hline $\mathrm{Ce}$ & 1.94 & 1.0 & 1.897 & 0.0572 & 3.3 & 0.052 \\
\hline $\operatorname{Pr}$ & 0.383 & 0.3 & 0.378 & 0.00738 & 3.9 & 0.007 \\
\hline $\mathrm{Nd}$ & 2.44 & 0.4 & 2.38 & 0.028 & 2.9 & 0.026 \\
\hline $\mathrm{Sm}$ & 1.12 & 0.7 & 1.117 & 0.0054 & 4.5 & 0.005 \\
\hline $\mathrm{Eu}$ & 0.541 & 1.1 & 0.524 & 0.001 & 4.4 & 0.001 \\
\hline $\mathrm{Gd}$ & 1.92 & 1.9 & 1.85 & 0.006 & 4.5 & 0.007 \\
\hline $\mathrm{Tb}$ & 0.373 & 0.4 & 0.379 & 0.0011 & 4.0 & 0.001 \\
\hline Dy & 2.65 & 1.2 & 2.53 & 0.00952 & 4.3 & 0.011 \\
\hline Но & 0.592 & 0.5 & 0.585 & 0.00285 & 2.3 & 0.003 \\
\hline Er & 1.76 & 1.3 & 1.734 & 0.0117 & 3.2 & 0.011 \\
\hline $\mathrm{Yb}$ & 1.69 & 0.8 & 1.649 & 0.0227 & 2.9 & 0.022 \\
\hline $\mathrm{Lu}$ & 0.249 & 1.6 & 0.247 & 0.00472 & 3.5 & 0.005 \\
\hline $\mathrm{Hf}$ & 0.59 & 0.8 & 0.562 & 0.006 & 20 & 0.005 \\
\hline Ta & 0.056 & 4.5 & 0.041 & - & - & 0.001 \\
\hline W & & & & 0.013 & 9.3 & \\
\hline $\mathrm{Pb}$ & 2.99 & 7.6 & 2.97 & 7.57 & 4.7 & 8.7 \\
\hline Th & 0.0307 & 0.3 & 0.0302 & 0.0109 & 1.3 & 0.011 \\
\hline $\mathrm{U}$ & 0.0099 & 2.7 & 0.010 & 0.004 & 4.4 & 0.004 \\
\hline
\end{tabular}

dominated by the composition of the orthopyroxene. Deviations from the orthopyroxene compositions can be explained by the presence of small amounts of chromite, feldspar-rich glass, and phosphates. Other phases are not present in sufficient abundance to contribute significantly to the major element budget. From mass balance considerations, we have estimated the mineralogical composition of each of the chips (Table 2) using the average compositions of the phases mainly obtained by Mittlefehldt (1994). The major element 
Table 2. New major and trace element abundances (oxides in $\mathrm{wt} \%$, traces elements in $\mu \mathrm{g} \mathrm{g}^{-1}$ ), and estimated proportions (wt\%) of phases for ALH 84001 (U: unleached fraction, R: residue, L1: first leach). The $\mathrm{P}_{2} \mathrm{O}_{5}$ abundances of the L-fractions have been fixed to $46 \mathrm{wt} \%$.

\begin{tabular}{|c|c|c|c|c|c|c|c|c|c|c|c|c|}
\hline \multirow[b]{3}{*}{ Mass (g) } & \multicolumn{3}{|c|}{ ALH 84001,405} & \multicolumn{3}{|c|}{ ALH 84001,406} & \multicolumn{3}{|c|}{ ALH 84001,407} & \multicolumn{3}{|c|}{ ALH 84001,408} \\
\hline & & 0.27 & & & 0.15 & & & 0.26 & & & 0.28 & \\
\hline & $405 \mathrm{U}$ & $405 \mathrm{R}$ & $405 \mathrm{~L} 1$ & $406 \mathrm{U}$ & 406R & 406L1 & $407 \mathrm{U}$ & $407 \mathrm{R}$ & 407L1 & $408 \mathrm{U}$ & $408 \mathrm{R}$ & $408 \mathrm{~L} 1$ \\
\hline $\mathrm{TiO}_{2}$ & 0.214 & 0.207 & & 0.167 & 0.174 & & 0.194 & 0.186 & & 0.195 & 0.217 & \\
\hline $\mathrm{Al}_{2} \mathrm{O}_{3}$ & 1.16 & 0.99 & & 0.84 & 0.85 & & 0.99 & 0.94 & & 1.01 & 1.02 & \\
\hline $\mathrm{Cr}_{2} \mathrm{O}_{3}$ & 1.27 & 1.21 & & 0.52 & 0.62 & & 0.89 & 0.75 & & 1.07 & 1.22 & \\
\hline $\mathrm{FeO}$ & 17.5 & 17.2 & & 17.7 & 17.1 & & 17.5 & 17.8 & & 17.0 & 17.8 & \\
\hline $\mathrm{MnO}$ & 0.44 & 0.45 & & 0.47 & 0.45 & & 0.47 & 0.43 & & 0.43 & 0.45 & \\
\hline $\mathrm{MgO}$ & 23.5 & 25.4 & & 25.5 & 24.7 & & 24.8 & 24.0 & & 23.2 & 24.4 & \\
\hline $\mathrm{CaO}$ & 1.87 & 1.76 & & 1.86 & 1.66 & & 1.94 & 1.73 & & 1.79 & 1.77 & \\
\hline $\mathrm{Na}_{2} \mathrm{O}$ & 0.12 & 0.08 & & 0.06 & 0.05 & & 0.08 & 0.06 & & 0.11 & 0.07 & \\
\hline $\mathrm{K}_{2} \mathrm{O}$ & 0.0176 & 0.0114 & & 0.0101 & 0.0108 & & 0.0185 & 0.0142 & & 0.0171 & 0.0121 & \\
\hline $\mathrm{P}_{2} \mathrm{O}_{5}$ & 0.0446 & 0.0038 & 46 & 0.0681 & 0.0032 & 46 & 0.0348 & 0.0031 & 46 & 0.0171 & 0.0039 & 46 \\
\hline Orthopx. & 96.51 & 97.39 & & 98.85 & 98.82 & & 97.78 & 98.28 & & 97.55 & 97.27 & \\
\hline Chromite & 1.85 & 1.71 & & 0.26 & 0.45 & & 1.04 & 0.73 & & 1.26 & 1.73 & \\
\hline Feldspar & 1.55 & 0.90 & & 0.75 & 0.73 & & 1.12 & 0.99 & & 1.16 & 1.00 & \\
\hline Phosphate & 0.09 & 0.00 & 100 & 0.14 & 0.00 & 100 & 0.07 & 0.00 & 100 & 0.03 & 0.00 & 100 \\
\hline $\mathrm{Li}$ & 2.24 & 2.24 & & 2.71 & 2.67 & & 2.49 & 2.49 & & 2.25 & 2.29 & \\
\hline $\mathrm{Be}$ & 0.044 & 0.038 & & 0.066 & 0.035 & & 0.041 & 0.034 & & 0.043 & 0.037 & \\
\hline $\mathrm{K}$ & 146 & 95 & & 84 & 89 & & 153 & 118 & & 142 & 101 & \\
\hline $\mathrm{Sc}$ & 13.18 & 13.56 & & 13.94 & 13.46 & & 13.47 & 13.06 & & 13.03 & 13.30 & \\
\hline V & 223 & 206 & & 141 & 148 & & 181 & 162 & & 190 & 215 & \\
\hline $\mathrm{Mn}$ & 3440 & 3488 & & 3624 & 3469 & & 3664 & 3349 & & 3340 & 3450 & \\
\hline $\mathrm{Co}$ & 43.72 & 44.07 & & 45.12 & 45.32 & & 47.03 & 45.27 & & 41.96 & 46.01 & \\
\hline $\mathrm{Ni}$ & 5.35 & 4.35 & & 4.94 & 4.39 & & 6.90 & 4.71 & & 5.40 & 4.78 & \\
\hline $\mathrm{Cu}$ & & & & 1.41 & & & 0.21 & & & & 0.10 & \\
\hline $\mathrm{Zn}$ & 73.0 & 73.0 & & 59.6 & 63.4 & & 71.6 & 64.1 & & 69.5 & 73.0 & \\
\hline $\mathrm{Ga}$ & 3.16 & 2.98 & & 2.12 & 2.29 & & 2.73 & 2.48 & & 2.81 & 3.06 & \\
\hline $\mathrm{Rb}$ & 0.43 & 0.30 & & 0.29 & 0.33 & & 0.58 & 0.48 & & 0.43 & 0.31 & \\
\hline $\mathrm{Sr}$ & 4.05 & 2.58 & & 2.09 & 1.81 & & 3.27 & 2.06 & & 3.08 & 2.38 & \\
\hline $\mathrm{Y}$ & 2.25 & 2.02 & 266 & 2.25 & 1.95 & 205 & 2.04 & 1.83 & 367 & 2.10 & 1.91 & 724 \\
\hline $\mathrm{Zr}$ & 6.09 & 5.21 & 229 & 4.79 & 4.57 & 96 & 6.14 & 5.26 & 230 & 6.42 & 5.56 & 728 \\
\hline $\mathrm{Nb}$ & 0.56 & 0.50 & & 0.38 & 0.35 & & 0.51 & 0.46 & & 0.54 & 0.56 & \\
\hline Mo & 0.08 & 0.10 & & 0.07 & 0.09 & & 0.07 & 0.08 & & 0.07 & 0.08 & \\
\hline Cs & 0.033 & 0.019 & & 0.023 & 0.015 & & 0.031 & 0.017 & & 0.032 & 0.017 & \\
\hline $\mathrm{Ba}$ & 2.50 & 1.66 & & 1.28 & 1.42 & & 2.28 & 1.81 & & 2.06 & 1.69 & \\
\hline $\mathrm{La}$ & 0.179 & 0.0253 & 151 & 0.247 & 0.0202 & 137 & 0.150 & 0.0212 & 173 & 0.168 & 0.0301 & 437 \\
\hline $\mathrm{Ce}$ & 0.454 & 0.0773 & 368 & 0.621 & 0.0662 & 337 & 0.357 & 0.0670 & 416 & 0.420 & 0.0893 & 1039 \\
\hline $\operatorname{Pr}$ & 0.0674 & 0.0154 & 51.54 & 0.0915 & 0.0137 & 46.85 & 0.0534 & 0.0133 & 57.20 & 0.0618 & 0.0168 & 141 \\
\hline $\mathrm{Nd}$ & 0.343 & 0.102 & 232 & 0.449 & 0.0960 & 215 & 0.270 & 0.0916 & 256 & 0.307 & 0.107 & 626 \\
\hline $\mathrm{Sm}$ & 0.125 & 0.0649 & 58.07 & 0.145 & 0.0624 & 51.77 & 0.101 & 0.0572 & 65.39 & 0.114 & 0.0628 & 154 \\
\hline $\mathrm{Eu}$ & 0.0399 & 0.0206 & 13.83 & 0.0282 & 0.0141 & 9.47 & 0.0335 & 0.0191 & 17.54 & 0.0331 & 0.0223 & 19.76 \\
\hline
\end{tabular}


Table 2. Continued. New major and trace element abundances (oxides in $\mathrm{wt} \%$, traces elements in $\mu \mathrm{g} \mathrm{g}^{-1}$, and estimated proportions (wt $\%$ ) of phases for ALH 84001 (U: unleached fraction, R: residue, L1: first leach). The P2O5 abundances of the L-fractions have been fixed to $46 \mathrm{wt} \%$.

\begin{tabular}{|c|c|c|c|c|c|c|c|c|c|c|c|c|}
\hline \multirow{3}{*}{ Mass (g) } & \multicolumn{3}{|c|}{ ALH 84001,405} & \multicolumn{3}{|c|}{ ALH 84001,406} & \multicolumn{3}{|c|}{ ALH 84001,407} & \multicolumn{3}{|c|}{ ALH 84001,408} \\
\hline & & 0.27 & & & 0.15 & & & 0.26 & & & 0.28 & \\
\hline & $405 \mathrm{U}$ & $405 \mathrm{R}$ & $405 \mathrm{~L} 1$ & $406 \mathrm{U}$ & $406 \mathrm{R}$ & 406L1 & $407 \mathrm{U}$ & $407 \mathrm{R}$ & $407 \mathrm{L1}$ & $408 \mathrm{U}$ & $408 \mathrm{R}$ & 408L1 \\
\hline Gd & 0.213 & 0.150 & 60.93 & 0.231 & 0.142 & 53.95 & 0.178 & 0.130 & 73.83 & 0.189 & 0.138 & 170 \\
\hline $\mathrm{Tb}$ & 0.0443 & 0.0353 & 8.88 & 0.0448 & 0.0338 & 7.31 & 0.0376 & 0.0314 & 11.31 & 0.0401 & 0.0328 & 24.63 \\
\hline Dy & 0.327 & 0.278 & 49.58 & 0.327 & 0.270 & 39.09 & 0.286 & 0.253 & 64.59 & 0.304 & 0.264 & 133 \\
\hline Ho & 0.0802 & 0.0710 & 9.42 & 0.0790 & 0.0688 & 7.22 & 0.0710 & 0.0653 & 12.77 & 0.0752 & 0.0671 & 24.94 \\
\hline $\mathrm{Er}$ & 0.259 & 0.235 & 24.05 & 0.254 & 0.227 & 17.77 & 0.234 & 0.222 & 33.77 & 0.246 & 0.226 & 60.57 \\
\hline $\mathrm{Yb}$ & 0.304 & 0.284 & 18.74 & 0.292 & 0.280 & 13.25 & 0.280 & 0.276 & 28.64 & 0.295 & 0.276 & 41.18 \\
\hline $\mathrm{Lu}$ & 0.0485 & 0.0452 & 2.66 & 0.0466 & 0.0447 & 1.84 & 0.0450 & 0.0442 & 4.15 & 0.0475 & 0.0445 & 5.59 \\
\hline $\mathrm{Hf}$ & 0.16 & 0.13 & 3.78 & 0.11 & 0.11 & 1.71 & 0.15 & 0.14 & 3.59 & 0.17 & 0.15 & 12.43 \\
\hline $\mathrm{Ta}$ & 0.029 & 0.021 & & 0.018 & 0.020 & & 0.024 & 0.023 & & 0.025 & 0.026 & \\
\hline W & 0.057 & 0.030 & & 0.048 & 0.020 & & 0.038 & 0.033 & & 0.028 & 0.037 & \\
\hline $\mathrm{Pb}$ & 0.008 & & & 0.006 & & & 0.036 & 0.029 & & 0.007 & & \\
\hline Th & 0.0375 & 0.0117 & 23.90 & 0.0408 & 0.0091 & 18.07 & 0.0320 & 0.0118 & 26.58 & 0.0351 & 0.0151 & 53.21 \\
\hline $\mathrm{U}$ & 0.0096 & 0.0058 & 3.92 & 0.0109 & 0.0052 & 3.57 & 0.0101 & 0.0051 & 7.37 & 0.0077 & 0.0047 & 6.26 \\
\hline
\end{tabular}


abundances of the unleached powders can be satisfactorily reconstructed without carbonates, using orthopyroxene, chromite, feldspar-rich glass, and phosphate compositions only, although carbonates were certainly present in very small amounts.

Trace element abundances obtained on the four chips are in good agreement with literature results (e.g., Dreibus et al. 1994; Mittlefehldt 1994; Gleason et al. 1997; Kong et al. 1999; Warren et al. 1999), but the Zn abundances obtained here are lower than previous determinations (Table 3), and point to a possible analytical bias. The four chips display similar rare earth element (REE) abundances (Table 2; Fig. 2). REE patterns are fairly flat from $\mathrm{La}$ to $\mathrm{Sm}\left(\mathrm{La}_{n} / \mathrm{Sm}_{n}=0.9\right.$ 1.06) and have significant heavy REE enrichments $\left(\mathrm{Gd}_{n} / \mathrm{Lu}_{n}=0.49-0.62\right)$. They all display negative $\mathrm{Eu}$ anomalies $\left(\mathrm{Eu} / \mathrm{Eu}^{*}=0.47-0.76\right)$.

\section{Residues}

The residues display the major element compositions similar to those of the unleached powders. The most noticeable differences are for the $\mathrm{P}_{2} \mathrm{O}_{5}$ abundances which are uniformly low, from 0.0031 to $0.0039 \mathrm{wt} \%$. Our leaching procedure has removed the phosphates from the powders, and these very small amounts of $\mathrm{P}$ are almost certainly hosted in the silicate phases. Moreover, the light REE abundances are much lower in the residues than in the unleached powders (Table 2; Fig. 2). The REE patterns of the residues display marked light REE depletions $\left(\mathrm{La}_{n} / \mathrm{Sm}_{n}=0.20\right.$ $0.30)$ and have negative $\mathrm{Eu}$ anomalies similar in magnitude to those of the unleached powders $\left(\mathrm{Eu} / \mathrm{Eu}^{*}=0.46-0.73\right)$. They are largely controlled by the orthopyroxenes, but the presence of feldspar-rich glass is required to explain some of these data (e.g., strong correlation of the $[\mathrm{Sr} / \mathrm{Ce}]_{n}$ and $\mathrm{Eu} / \mathrm{Eu}^{*}$ ratios [not shown]). Indeed, the mineralogical compositions of the residues, as previously estimated from major element abundances, point to a small contribution of feldspar-rich glass (about $0.7-1 \mathrm{wt} \%$; Table 2).

\section{Leachates}

A few major elements and all the trace elements listed in Table 2 were determined on these fractions. The data indicate that phosphates, traces of sulfides, carbonates, and possibly some feldspar-rich glasses were removed from the powders during the first step of leaching $\left(2 \mathrm{~m} \mathrm{HCl}, 50{ }^{\circ} \mathrm{C}, 30 \mathrm{~min}\right)$. We have voluntarily limited the data given in Table 2 to a few elements totally controlled by phosphates: Y, Zr, REEs, Hf, Th, and $\mathrm{U}$. Consequently, the concentrations of these elements were adjusted assuming a $\mathrm{P}_{2} \mathrm{O}_{5}$ concentration fixed to $46 \mathrm{wt} \%$ (as in phosphates found in ALH 84001, see Boctor et al. [2003] and Greenwood et al. [2003]). Carbonates have been previously analyzed by Eiler et al. (2002) and Corrigan et al. (2004) for trace elements, and their possible contributions do not affect the results. Because ALH 84001 contains both apatite and merrillite, the concentrations reported in Table 2 are good estimations of the average phosphate for each fraction. Unsurprisingly, these phases are REE-rich, with $\mathrm{La}$ and $\mathrm{Lu}$ abundances ranging respectively from 137 to 437 and 13.2 to $41.2 \mu \mathrm{g} \mathrm{g}^{-1}$. Their REE patterns (Fig. 2) are light REE enriched $\left(\mathrm{La}_{n} / \mathrm{Yb}_{n}=4.0-7.2\right)$ and display low $\mathrm{Eu} / \mathrm{Eu}^{*}$ ratios $(=0.42-0.83)$. The shapes of the patterns are similar to those of the two analyses of phosphates obtained previously by secondary ion mass spectrometry (SIMS) (Wadhwa and Crozaz 1998). Th and $U$ concentrations are high, ranging respectively from 18.07 to 53.21 and 3.5 to $7.4 \mu \mathrm{g} \mathrm{g}^{-1}$, again in agreement with previous SIMS analyses (Terada et al. 2004).

\section{DISCUSSION}

\section{Bulk Composition of ALH 84001}

Obtaining a representative sample of a coarsegrained orthopyroxenite would require crushing and homogenization of much more than $100 \mathrm{~g}$ of sample. It is of course not realistic to obtain such large amounts of ALH 84001 for bulk rock analysis. The range of trace element abundances displayed by literature analyses and our new results (Tables 2 and 3) can be explained chiefly by different proportions of minor and trace phases in the chips.

Although none of the chips we have analyzed (weighing from 150 to $280 \mathrm{mg}$ ) can be considered representative of the whole rock, we have calculated a weighted average of our unleached powders (Table 3). We believe that this average composition obtained from fragments taken from different regions of the meteorite and totaling about $1 \mathrm{~g}$ of material is, at present, the best estimation of the bulk composition of ALH 84001. From this composition, we have estimated the proportions of the main phases present in ALH 84001 (Table 3, carbonates and sulfides have been neglected); these estimates are in agreement with modal compositions performed by point counting on thin sections (Meyer 2009). This mineralogical composition is an important parameter that will be used below.

\section{Trace Element Abundances of the Orthopyroxene}

The compositions of the ALH 84001 phases have been repeatedly determined for major elements and are 
Table 3. Major and trace element abundances of bulk ALH 84001 (oxides in wt $\%$, traces elements in $\mu \mathrm{g} \mathrm{g}^{-1}$, * $\mathrm{SiO}_{2}$ calculated by difference).

\begin{tabular}{|c|c|c|c|c|c|c|}
\hline & This work & $\begin{array}{l}\text { Mittlefehldt } \\
\text { (1994) }\end{array}$ & $\begin{array}{l}\text { Dreibus et al. } \\
\text { (1994) }\end{array}$ & $\begin{array}{l}\text { Gleason et al. } \\
\text { (1997) }\end{array}$ & $\begin{array}{l}\text { Warren et al. } \\
\text { (1999) }\end{array}$ & $\begin{array}{l}\text { Kong et al. } \\
\text { (1999) }\end{array}$ \\
\hline $\mathrm{SiO}_{2}$ & $53.9 *$ & & 52.7 & $50.3^{*}$ & 52.9 & $52.0^{*}$ \\
\hline $\mathrm{TiO}_{2}$ & 0.195 & & 0.200 & 0.220 & 0.199 & 0.252 \\
\hline $\mathrm{Al}_{2} \mathrm{O}_{3}$ & 1.02 & & 1.25 & 1.38 & 1.2 & 1.30 \\
\hline $\mathrm{Cr}_{2} \mathrm{O}_{3}$ & 0.99 & 1.00 & 1.24 & 1.19 & 1.17 & 1.18 \\
\hline $\mathrm{FeO}$ & 17.4 & & 17.6 & 18.4 & 17.4 & 18.3 \\
\hline $\mathrm{MnO}$ & 0.45 & & 0.44 & 0.46 & 0.47 & 0.51 \\
\hline $\mathrm{MgO}$ & 24.1 & & 24.5 & 26.1 & 24.7 & 24.2 \\
\hline $\mathrm{CaO}$ & 1.86 & 2.50 & 1.82 & 1.77 & 1.81 & 2.02 \\
\hline $\mathrm{Na}_{2} \mathrm{O}$ & 0.10 & 0.087 & 0.162 & 0.132 & 0.151 & 0.198 \\
\hline $\mathrm{K}_{2} \mathrm{O}$ & 0.017 & 0.003 & 0.022 & 0.015 & 0.015 & 0.030 \\
\hline $\mathrm{P}_{2} \mathrm{O}_{5}$ & 0.038 & & 0.014 & & & \\
\hline Orthopyroxene & 97.51 & & 96.22 & & & \\
\hline Chromite & 1.26 & & 1.95 & & & \\
\hline Feldspar & 1.16 & & 1.80 & & & \\
\hline Phosphate & 0.07 & & 0.03 & & & \\
\hline $\mathrm{Li}$ & 2.38 & & & & & \\
\hline $\mathrm{Be}$ & 0.046 & & & & & \\
\hline $\mathrm{K}$ & 137 & 27 & & & 122 & 250 \\
\hline $\mathrm{Sc}$ & 13.33 & 12.40 & 12.70 & 13.00 & 13.1 & 13.4 \\
\hline V & 189 & & & & 205 & 207 \\
\hline $\mathrm{Co}$ & 44.3 & 46.3 & 43.0 & 48.9 & 50.0 & 51.6 \\
\hline $\mathrm{Ni}$ & 5.72 & & $<20$ & & 6 & 2.6 \\
\hline $\mathrm{Zn}$ & 69.5 & & 106.0 & 91.6 & 86 & 103 \\
\hline $\mathrm{Ga}$ & 2.78 & & 3.20 & 3.24 & 2.7 & 5.7 \\
\hline $\mathrm{Rb}$ & 0.45 & & 0.83 & & & \\
\hline $\mathrm{Sr}$ & 3.25 & & 4.46 & & $<24$ & \\
\hline Y & 2.15 & & 1.63 & & & \\
\hline $\mathrm{Zr}$ & 6.00 & & 5.89 & & $<38$ & \\
\hline $\mathrm{Nb}$ & 0.51 & & 0.42 & & & \\
\hline Cs & 0.031 & & 0.040 & 0.045 & $<0.05$ & \\
\hline $\mathrm{Ba}$ & 2.12 & & 4.03 & & & \\
\hline $\mathrm{La}$ & 0.179 & 0.156 & 0.150 & 0.185 & 0.280 & 0.270 \\
\hline $\mathrm{Ce}$ & 0.444 & & 0.430 & & 0.700 & 0.300 \\
\hline $\operatorname{Pr}$ & 0.0657 & & 0.0600 & & & \\
\hline $\mathrm{Nd}$ & 0.330 & & 0.265 & & $<0.9$ & \\
\hline $\mathrm{Sm}$ & 0.118 & 0.107 & 0.104 & 0.114 & 0.163 & 0.14 \\
\hline $\mathrm{Eu}$ & 0.0344 & 0.0230 & 0.0320 & 0.0400 & 0.045 & 0.0556 \\
\hline $\mathrm{Gd}$ & 0.200 & & 0.140 & & & 0.17 \\
\hline $\mathrm{Tb}$ & 0.0413 & 0.0360 & 0.0300 & 0.0390 & 0.042 & 0.062 \\
\hline Dy & 0.309 & & 0.240 & 0.310 & $<0.7$ & \\
\hline Но & 0.0761 & & 0.0680 & 0.0810 & 0.07 & \\
\hline $\mathrm{Er}$ & 0.248 & & 0.210 & & & \\
\hline $\mathrm{Yb}$ & 0.293 & 0.270 & 0.255 & 0.317 & 0.3 & 0.347 \\
\hline $\mathrm{Lu}$ & 0.0469 & 0.0450 & 0.0370 & 0.0530 & 0.05 & 0.0601 \\
\hline $\mathrm{Hf}$ & 0.152 & 0.120 & 0.160 & 0.180 & 0.111 & 0.2 \\
\hline Ta & 0.025 & & $<0.04$ & 0.032 & $<0.06$ & \\
\hline W & 0.042 & & & 0.079 & & \\
\hline $\mathrm{Pb}$ & 0.0148 & & 0.0720 & & & \\
\hline Th & 0.0358 & & 0.0350 & & 0.11 & \\
\hline $\mathrm{U}$ & 0.0094 & & 0.0100 & & $<0.03$ & \\
\hline
\end{tabular}

today well known. Mittlefehldt (1994) demonstrated that these compositions are fairly homogeneous for the major elements, and that igneous zoning in the silicates, if initially present, has been largely erased by subsolidus equilibration. Data on trace elements in the ALH 84001 silicates are more limited, but some variability has been 

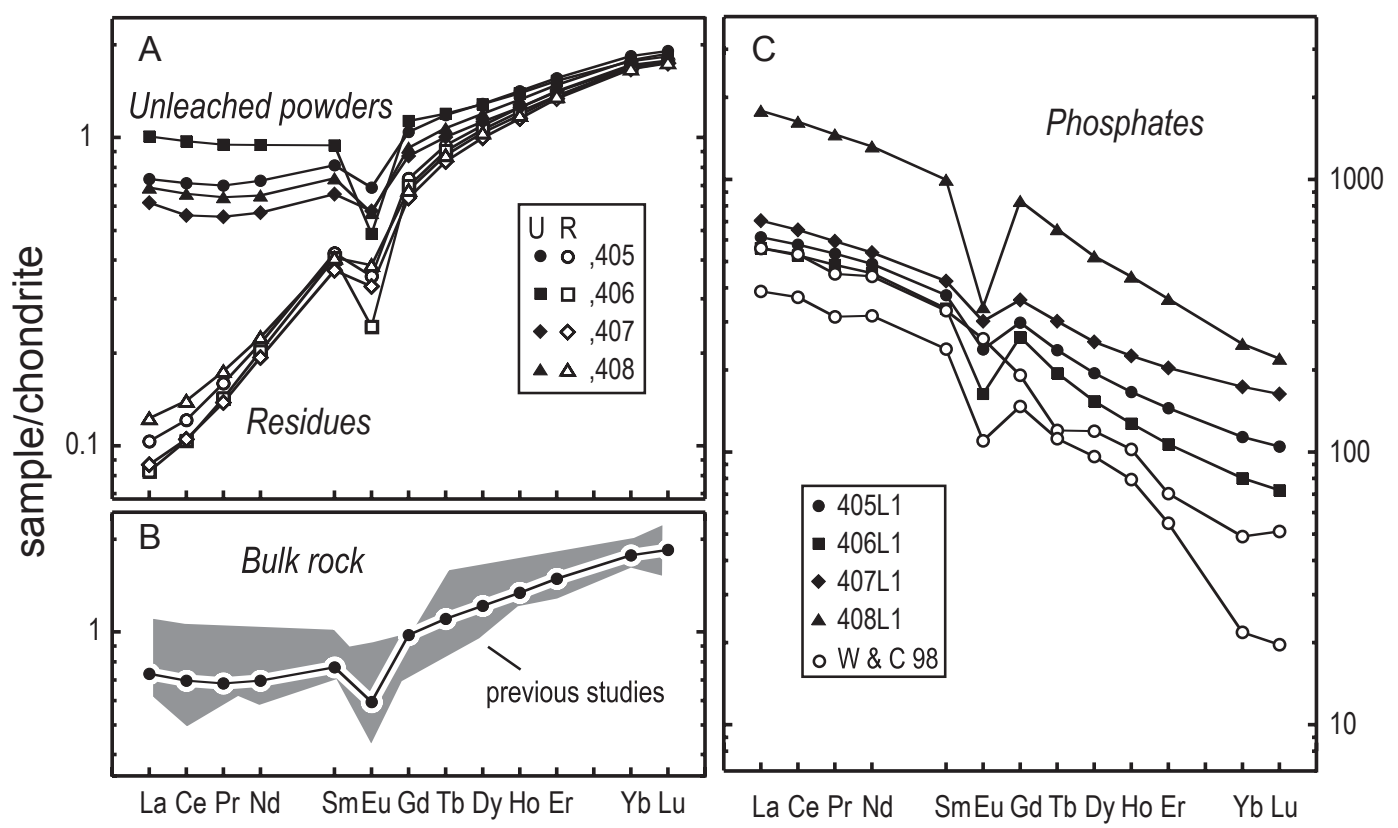

Fig. 2. A) REE patterns of the four chips (U: unleached fraction; R: residue) of ALH 84001 analyzed in this study. B) REE pattern of the bulk rock compared with literature results (Dreibus et al. 1994; Mittlefehldt 1994; Kong et al. 1999; Warren et al. 1999). C) REE patterns of the phosphates from ALH 84001 (this study and Wadhwa and Crozaz 1998). The reference chondrite is from Evensen et al. (1978).

suggested (Papike et al. 1994; Wadhwa and Crozaz 1998; Righter et al. 2009a). The data obtained on the unleached powders and on the residues allow a discussion of the chemical homogeneity of the orthopyroxene.

The proportions of chromite strongly control not only the $\mathrm{Cr}$ abundances, but also the abundances of $\mathrm{Ti}$, $\mathrm{V}, \mathrm{Ga}$ and $\mathrm{Zn}$, and, to some extend, $\mathrm{Al}$ in the samples. The striking relationships obtained in the $\mathrm{TiO}_{2}, \mathrm{~V}, \mathrm{Ga}$, $\mathrm{Zn}$ versus $\mathrm{Cr}_{2} \mathrm{O}_{3}$ (Fig. 3) indicate that the abundances of these elements in bulk orthopyroxene and bulk chromite are rather homogeneous at the scale of a 150 $250 \mathrm{mg}$ chip. Furthermore, using the average $\mathrm{Cr}_{2} \mathrm{O}_{3}$ abundance of the orthopyroxene (Mittlefehldt 1994), it is possible to estimate its concentrations of $\mathrm{Zn}, \mathrm{Ga}$, and $\mathrm{V}$ from these relationships (Table 4). The $\mathrm{Al}_{2} \mathrm{O}_{3}$ versus $\mathrm{Cr}_{2} \mathrm{O}_{3}$ plot (Fig. 3) displays a weaker correlation, because feldspar-rich glass and chromite control both the aluminum budget.

The REE abundances of the feldspar-rich glass have been previously determined by Wadhwa and Crozaz (1998) and are given in Table 5. Because the mineralogical compositions of the four residues have been estimated (Table 2), it is possible to calculate the REE abundances in the orthopyroxene for each of these fractions. Notice that the heavy REE abundances in the feldspar-rich glass are extremely low and could not be determined by Wadhwa and Crozaz (1998). Similarly, chromites in ALH 84001 have insignificant REE abundances (Righter et al. 2009a). These low concentrations have no impact in the calculations. The $\mathrm{Zr}$ and $\mathrm{Hf}$ concentrations in the orthopyroxene can be obtained from the same line of reasoning. The results are similar for the four residues and the average concentrations are compared with previous determinations in Table 4 and in Fig. 4. Our values are indistinguishable to the data obtained by Wadhwa and Crozaz (1998) from $\mathrm{Sm}$ to $\mathrm{Lu}$, but our light REE abundances are somewhat higher, and are similar to the recent laser-ICP-MS analyses made by Righter et al. (2009a). These new results confirm that our estimations of the trace element abundances in orthopyroxene are robust.

\section{The Parental Melt of ALH 84001}

\section{Chemical Features of the ALH 84001 Parental Melt}

While the cumulate origin of ALH 84001 is widely accepted, the composition of its parental melt is still a mystery. However, some of its chemical features can be deduced from the major element composition of the orthopyroxene, and from trace elements abundances.

The low-Ca pyroxene $\mathrm{K}_{\mathrm{D}}(\mathrm{Fe} / \mathrm{Mg}$ ) (about 0.27 ) is well determined for basaltic systems (Stolper 1977; Bartels and Grove 1991), and it is extremely tempting to estimate the $\mathrm{FeO} / \mathrm{MgO}$ ratio of the ALH 84001 parental melt from this value. Unfortunately, the orthopyroxenes do not show any clear evidence of 


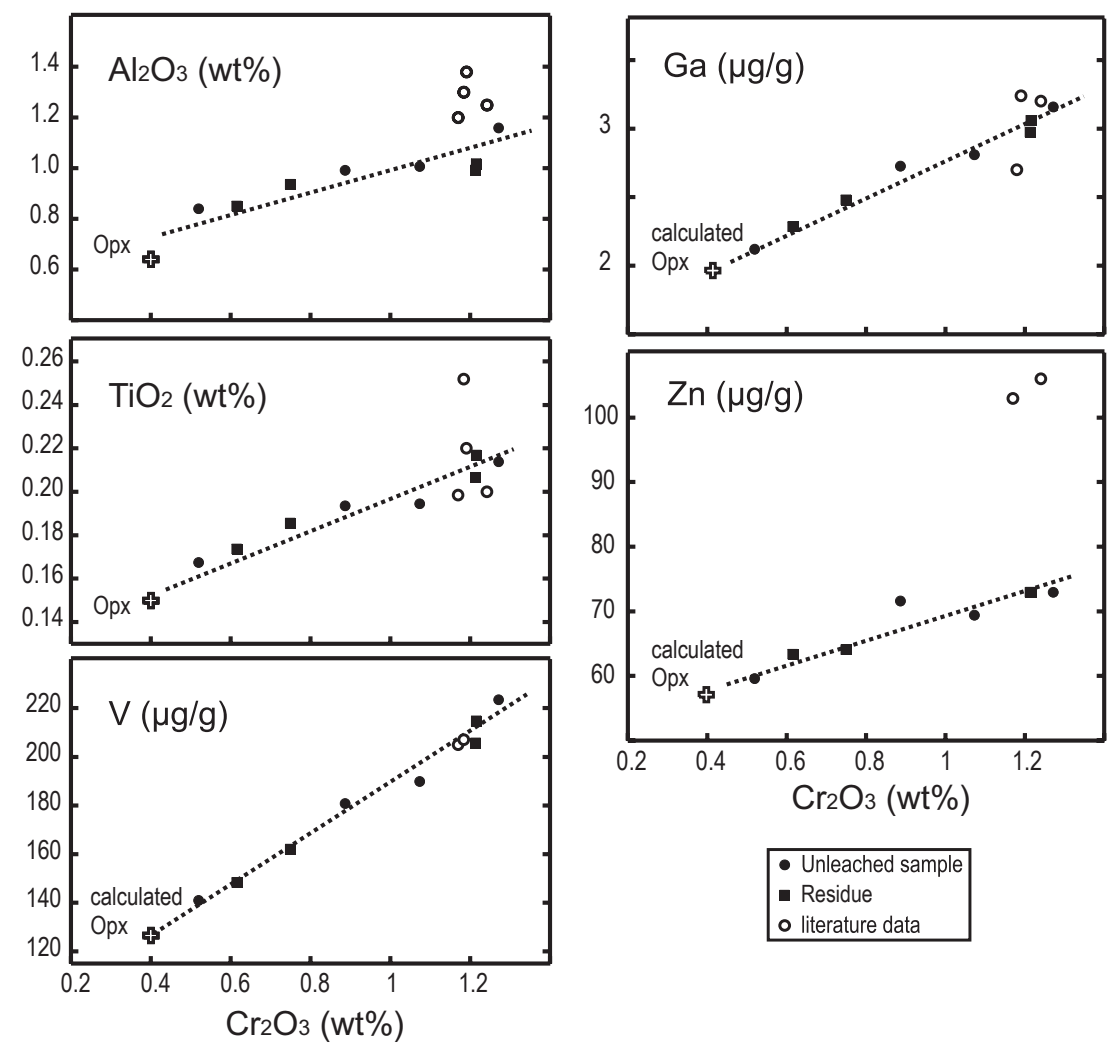

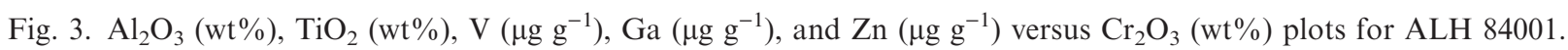

Table 4. Trace element abundances of orthopyroxene in ALH 84001 (in $\mu \mathrm{g} \mathrm{g}^{-1}$ ).

\begin{tabular}{|c|c|c|c|c|c|c|}
\hline & \multicolumn{3}{|l|}{ This study } & \multirow[b]{2}{*}{ Papike et al. (1994) } & \multirow[b]{2}{*}{ Wadhwa and Crozaz (1998) } & \multirow[b]{2}{*}{ Righter et al. (2009a, 2009b) } \\
\hline & Extrapolated & $n=4$ & $1-\sigma$ & & & \\
\hline V & 127 & & & & & \\
\hline $\mathrm{Zn}$ & 59 & & & & & \\
\hline $\mathrm{Ga}$ & 2.0 & & & & & \\
\hline $\mathrm{Zr}$ & & 5.17 & 0.42 & 2.8 & & \\
\hline $\mathrm{La}$ & & 0.0168 & 0.0041 & 0.005 & 0.0069 & \\
\hline $\mathrm{Ce}$ & & 0.0642 & 0.0107 & 0.033 & 0.0342 & \\
\hline $\operatorname{Pr}$ & & 0.0139 & 0.0017 & & 0.0079 & \\
\hline $\mathrm{Nd}$ & & 0.0976 & 0.0071 & 0.069 & 0.0738 & \\
\hline $\mathrm{Sm}$ & & 0.0628 & 0.0036 & 0.063 & 0.0491 & \\
\hline $\mathrm{Eu}$ & & 0.0072 & 0.0023 & 0.01 & 0.0059 & \\
\hline Gd & & 0.143 & 0.009 & & 0.0992 & \\
\hline $\mathrm{Tb}$ & & 0.0340 & 0.0018 & & 0.0316 & \\
\hline Dy & & 0.272 & 0.011 & 0.196 & 0.269 & \\
\hline Но & & 0.0695 & 0.0026 & & 0.0627 & \\
\hline Er & & 0.232 & 0.006 & 0.147 & 0.225 & \\
\hline $\mathrm{Yb}$ & & 0.285 & 0.005 & 0.191 & 0.314 & \\
\hline $\mathrm{Lu}$ & & 0.046 & 0.001 & & 0.0530 & 0.0486 \\
\hline $\mathrm{Hf}$ & & 0.13 & 0.01 & & & 0.1168 \\
\hline
\end{tabular}

zoning (Mittlefehldt 1994), and display homogeneous compositions for major elements. If the crystals displayed initially a normal zoning, their actual $\mathrm{FeO} / \mathrm{MgO}$ ratios $(=0.70$, Mittlefehldt 1994) are higher than those of their initial cores. Therefore, an upper limit for the $\mathrm{FeO} / \mathrm{MgO}$ ratio of the parental melt can be deduced from this value $\left([\mathrm{FeO} / \mathrm{MgO}]_{\text {parental melt }}\right.$ $<2.6$ ). Moreover, this upper limit and the true value 
Table 5. Trace element abundances in phases (in $\mu \mathrm{g} \mathrm{g}^{-1}$ ), element ratios, equilibrium partition coefficients for orthopyroxene (derived from a'Schwandt and McKay 1998; 'Adam and Green 2006) used for calculations. The "apparent" partition coefficients for orthopyroxene calculated for trapped melt proportions of $1 \%, 5 \%$, and $10 \%$ are given for comparison. The $\mathrm{Zr}$ concentration of the chromite is deduced from the $\mathrm{Hf}$ concentration assuming a chondritic ratio.

\begin{tabular}{|c|c|c|c|c|c|c|c|c|c|c|c|}
\hline & Orthopyroxene & $\begin{array}{l}\text { Feldsp. glass } \\
\text { Wadhwa and }\end{array}$ & $\begin{array}{l}\text { Chromite } \\
\text { Righter et al. }\end{array}$ & $\begin{array}{l}\text { Phosphate } \\
\text { weighted av. }\end{array}$ & $\begin{array}{l}\text { Phase/orth } \\
\text { partition c }\end{array}$ & $\begin{array}{l}\text { pyroxene } \\
\text { eff. }\end{array}$ & & & Apparent & Partition & Coefficients \\
\hline & $\left(\mu \mathrm{g} \mathrm{g}^{-1}\right)$ & $\left(\mu \mathrm{g} \mathrm{g}^{-1}\right)$ & $\left(\mu \mathrm{g} \mathrm{g}^{-1}\right)$ & $\left(\mu \mathrm{g} \mathrm{g}^{-1}\right)$ & Chr/Opx & Feld/Opx & Phos/Opx & $D_{\mathrm{opx} / \mathrm{melt}}$ & $\phi=0.01$ & $\phi=0.05$ & $\phi=0.1$ \\
\hline $\mathrm{La}$ & 0.0168 & 0.86 & & 238 & Negligible & 50.96 & 14158 & $0.0004^{\mathrm{a}}$ & 0.0009 & 0.0042 & 0.0083 \\
\hline $\mathrm{Ce}$ & 0.0642 & 1.35 & & 572 & Negligible & 20.97 & 8913 & $0.0011^{\mathrm{a}}$ & 0.0014 & 0.0065 & 0.0129 \\
\hline $\operatorname{Pr}$ & 0.0139 & 0.13 & & 78.40 & Negligible & 9.22 & 5625 & $0.0020^{\mathrm{a}}$ & 0.0023 & 0.0099 & 0.0194 \\
\hline $\mathrm{Nd}$ & 0.0976 & 0.38 & & 351 & Negligible & 3.88 & 3594 & $0.0039^{\mathrm{a}}$ & 0.0038 & 0.0146 & 0.0281 \\
\hline $\mathrm{Zr}$ & 5.17 & & $7.89 *$ & 354 & 1.5 & Negligible & 68.5 & $0.0099^{\mathrm{b}}$ & 0.0188 & 0.0565 & 0.104 \\
\hline Hf & 0.13 & & 0.2192 & 5.93 & 1.7 & Negligible & 45.6 & $0.0170^{\mathrm{b}}$ & 0.0259 & 0.0640 & 0.112 \\
\hline $\mathrm{Sm}$ & 0.0628 & 0.039 & & 86.99 & Negligible & 0.62 & 1386 & $0.0113^{\mathrm{a}}$ & 0.0106 & 0.0302 & 0.0549 \\
\hline $\mathrm{Eu}$ & 0.0072 & 1.33 & & 15.89 & Negligible & 185 & 2212 & $0.0042^{\mathrm{a}}$ & 0.0030 & 0.0114 & 0.0218 \\
\hline Gd & 0.143 & 0.048 & & 95.25 & Negligible & 0.33 & 667 & $0.0238^{\mathrm{a}}$ & 0.0228 & 0.0493 & 0.0824 \\
\hline $\mathrm{Tb}$ & 0.0340 & 0.007 & & 13.89 & Negligible & 0.21 & 409 & $0.0345^{\mathrm{a}}$ & 0.0345 & 0.0647 & 0.102 \\
\hline Dy & 0.272 & & & 76.30 & Negligible & Negligible & 281 & $0.0501^{\mathrm{a}}$ & 0.0504 & 0.0825 & 0.123 \\
\hline Ho & 0.0695 & & & 14.51 & Negligible & Negligible & 209 & $0.0670^{\mathrm{a}}$ & 0.0676 & 0.101 & 0.142 \\
\hline $\mathrm{Er}$ & 0.232 & & & 36.35 & Negligible & Negligible & 156 & $0.090^{\mathrm{a}}$ & 0.091 & 0.124 & 0.166 \\
\hline $\mathrm{Yb}$ & 0.285 & & & 27.11 & Negligible & Negligible & 95.2 & $0.103^{\mathrm{a}}$ & 0.107 & 0.141 & 0.184 \\
\hline $\mathrm{Lu}$ & 0.0456 & & 0.000744 & 3.79 & Negligible & Negligible & 83.1 & $0.110^{\mathrm{a}}$ & 0.115 & 0.149 & 0.192 \\
\hline
\end{tabular}




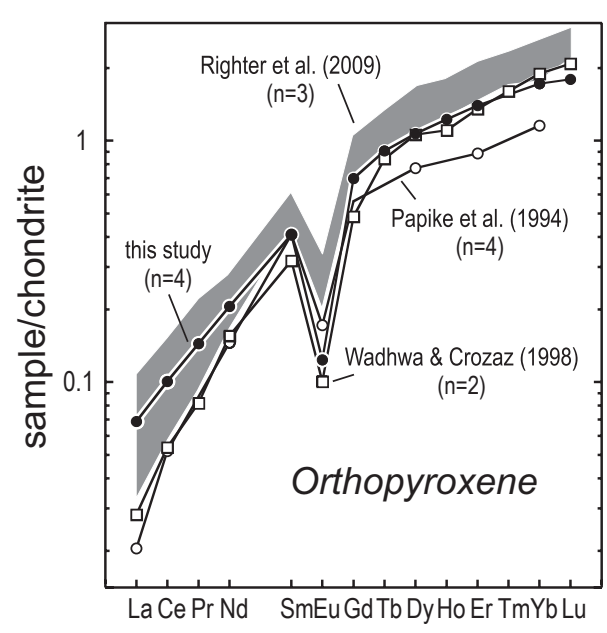

Fig. 4. REE patterns of the orthopyroxenes from ALH 84001. The reference chondrite is from Evensen et al. (1978).

may not be very different. Mittlefehldt et al. (1995) described possible remnant igneous zoning in an orthopyroxene from its $\mathrm{Ti}$ distribution, and suggested that the crystals displayed initially a limited rim. Thus, the average compositions of the crystals may be similar to that of their cores and hence could still provide useful constraints on the composition of the parental melt. If this assumption is valid, then an evolved mafic melt can be inferred from a $\mathrm{FeO} / \mathrm{MgO}$ value close to 2.5-2.6. This suggestion is strengthened by the very low siderophile trace element abundances displayed by the whole rock (Warren et al. 1999) as exemplified here by the low $\mathrm{Ni}$ abundance (about $5.7 \mu \mathrm{g} \mathrm{g}^{-1}$, Table 3). Because Ni behaves compatibly during orthopyroxene crystallization (e.g., Norman et al. 2005), the low Ni abundances measured in all the ALH 84001 fractions indicate that the ALH 84001 parental melt contained only a few $\mu \mathrm{g} \mathrm{g}^{-1}$ of $\mathrm{Ni}$, and possibly much less.

Estimates of the REE abundances of melt in equilibrium with ALH 84001 phases were previously calculated directly from mineral/melt partition coefficients and analyses of the phases (Papike et al. 1994; Wadhwa and Crozaz 1998). In both cases, it was concluded that orthopyroxene formed from a melt with heavy REEs about $10-20 \times \mathrm{CI}$, that was possibly slightly light REE depleted. In contrast, calculated melts in equilibrium with feldspar and phosphate exhibited strong light REE enrichments. These calculations led Wadhwa and Crozaz (1998) to propose that ALH 84001 was infiltrated by an unrelated light REE-enriched melt at a late stage of crystallization either concurrently with settling or immediately after accumulation of the orthopyroxene crystals.

If ALH 84001 was really affected by infiltration metasomatism, some additional petrographical and chemical confirmations are expected. Because the infiltrated melt was not genetically linked with the cumulus phases, textures suggesting some reaction between this melt and the orthopyroxene crystals should be observed in ALH 84001. However, this kind of textural evidence has never been described in this meteorite (Mittlefehldt et al. 1995). On the other hand, if orthopyroxene was stable with the infiltrated melt, the crystals should exhibit overgrowths formed from the latter. Although in situ analyses of trace elements in orthopyroxene demonstrate some heterogeneities possibly inherited from an original igneous zoning (Wadhwa and Crozaz 1998), no evidence of such overgrowths have been detected yet. Therefore, the hypothesis of infiltration metasomatism seems improbable.

Alternatively, the differences between the melts calculated by Wadhwa and Crozaz (1998) could be explained by the uncertainties on the partition coefficients available at that time. We have recalculated the melt in equilibrium with orthopyroxene for REEs using more recent estimates of the partition coefficients (Schwandt and McKay 1998), and obtain a parental melt displaying a marked light REE enrichment (Table 6; Fig. 5). Thus, one may suggest that ALH 84001 formed from a parental melt displaying a marked light REE enrichment. This hypothesis can be easily tested. We have recalculated the composition of the bulk rock assuming that ALH 84001 contains a few percent trapped melt (Mittlefehldt 1994). Because the light REE abundances of orthopyroxenes are very low, the involvement of small amounts of melt has a significant impact on the incompatible trace element budget, and a bulk rock displaying a light REE enrichment is obtained. Thus, such an enriched melt can be directly ruled out because it is inconsistent with the light REE budget of the bulk rock (Fig. 6).

As already pointed out by Treiman (1996), the partition coefficients calculated with the ALH 84001 phases (Table 5) indicate that the REE abundances were (at least partly) affected by subsolidus reequilibration. Therefore, the parental melt of ALH 84001 cannot be deduced from equilibrium mineral/melt partition coefficients. The spurious light REE enrichments displayed by the calculated melts in equilibrium with the phosphate or the feldspar-rich glass could be just artifacts well explained by the redistribution of REEs and the inadequacy of the equilibrium partition coefficients.

The abundances of some trace elements (REEs, Zr, Hf) in the ALH 84001 parental melt can, however, be constrained from the method described by Barrat (2004). Consider that ALH 84001 consists of two cumulus phases, orthopyroxene and chromite, initially in equilibrium with the melt in the magma chamber. A mass fraction of liquid $(\phi)$ was trapped in the 
Table 6. ALH 84001 parental melt estimated from the $\mathrm{FeO} / \mathrm{MgO}$ ratio (wt $\% / \mathrm{wt} \%$ ) of the orthopyroxene and the $\mathrm{Ni}$ abundance of the bulk rock (1), the trace element abundances of the orthopyroxene and the equilibrium partition coefficients (2), the trace element abundances of the orthopyroxene and the apparent partition coefficients for $\phi=2.5 \%$ (3), for $\phi=5 \%$ (4), and for $\phi=10 \%$ (5). The concentrations of trace elements in Zagami (Barrat et al. 2001) and Los Angeles (Jambon et al. 2002) are given for comparison (traces elements in $\underline{\left.\mu \mathrm{g} \mathrm{g}^{-1}\right)}$.

\begin{tabular}{|c|c|c|c|c|c|c|c|}
\hline & 1 & $\begin{array}{l}2 \\
\text { (equ. } D s \text { ) }\end{array}$ & $\begin{array}{l}3 \\
(\phi=2.5 \%)\end{array}$ & $\begin{array}{l}4 \\
(\phi=5 \%)\end{array}$ & $\begin{array}{l}5 \\
(\phi=10 \%)\end{array}$ & Zagami & Los Angeles \\
\hline $\mathrm{FeO} / \mathrm{MgO}$ & 2.5 & & & & & 1.55 & 5.39 \\
\hline $\mathrm{Ni}$ & $<2$ & & & & & 101 & 32 \\
\hline $\mathrm{Zr}$ & & 522 & 157 & 91 & 50 & 61.01 & 79.60 \\
\hline $\mathrm{La}$ & & 42.0 & 7.97 & 4.02 & 2.02 & 1.44 & 3.97 \\
\hline $\mathrm{Ce}$ & & 60.5 & 19.26 & 9.83 & 4.97 & 3.47 & 9.84 \\
\hline $\mathrm{Pr}$ & & 6.83 & 2.71 & 1.41 & 0.72 & 0.509 & 1.43 \\
\hline $\mathrm{Nd}$ & & 24.82 & 12.45 & 6.68 & 3.47 & 2.53 & 7.07 \\
\hline $\mathrm{Sm}$ & & 5.55 & 3.50 & 2.08 & 1.14 & 0.961 & 2.64 \\
\hline $\mathrm{Eu}$ & & 1.71 & 1.17 & 0.63 & 0.33 & 0.399 & 1.02 \\
\hline $\mathrm{Gd}$ & & 6.00 & 4.36 & 2.90 & 1.73 & 1.56 & 4.28 \\
\hline $\mathrm{Tb}$ & & 0.98 & 0.74 & 0.53 & 0.33 & 0.308 & 0.792 \\
\hline Dy & & 5.43 & 4.36 & 3.30 & 2.22 & 2.17 & 5.04 \\
\hline Ho & & 1.04 & 0.87 & 0.69 & 0.49 & 0.479 & 1.03 \\
\hline $\mathrm{Er}$ & & 2.59 & 2.26 & 1.88 & 1.40 & 1.34 & 2.76 \\
\hline $\mathrm{Yb}$ & & 2.77 & 2.38 & 2.01 & 1.55 & 1.22 & 2.35 \\
\hline $\mathrm{Lu}$ & & 0.41 & 0.36 & 0.31 & 0.24 & 0.186 & 0.331 \\
\hline $\mathrm{Hf}$ & & 7.65 & 3.23 & 2.03 & 1.17 & 1.54 & 2.19 \\
\hline$(\mathrm{La} / \mathrm{Sm})_{n}$ & & 4.76 & 1.43 & 1.22 & 1.11 & 0.94 & 0.95 \\
\hline$(\mathrm{Zr} / \mathrm{Sm})_{n}$ & & 3.74 & 1.78 & 1.75 & 1.74 & 2.53 & 1.20 \\
\hline$(\mathrm{Hf} / \mathrm{Sm})_{n}$ & & 1.99 & 1.33 & 1.41 & 1.47 & 2.32 & 1.20 \\
\hline
\end{tabular}

framework of the cumulus crystals. For a given element, the composition of the bulk rock $C_{\text {rock }}$ is:

$C_{\text {rock }}=\left(\phi+X_{\text {chr }} \times D_{\text {chr } / \text { melt }}+X_{\mathrm{opx}} \times D_{\text {opx } / \text { melt }}\right) C_{\mathrm{L}}$,

where $C_{\mathrm{L}}$ is the concentration of the element in the melt, $X_{\mathrm{chr}}$ and $X_{\mathrm{opx}}$ are the mass fractions of chromite and orthopyroxene, $D_{\text {chr/melt }}$ and $D_{\text {opx/melt }}$ the equilibrium partition coefficients. Note that $\phi+X_{\mathrm{chr}}+X_{\mathrm{opx}}=1$.

After crystallization of the trapped melt, and equilibration of the phases, the rock contains in addition to the cumulus phases, feldspar and phosphates. As pointed out before, the other phases are minor and are insignificant in the calculations. $Y_{\mathrm{opx}}, Y_{\mathrm{chr}}, Y_{\mathrm{fpr}}, Y_{\mathrm{ph}}$ are respectively the mass proportions of orthopyroxene, chromite, feldspar, and phosphate in the bulk rock, and $C_{\mathrm{opx}}, C_{\mathrm{chr}}, C_{\mathrm{fpr}}$, and $C_{\mathrm{ph}}$ their average composition. The bulk rock composition can be written as follow:

$C_{\text {rock }}=Y_{\mathrm{opx}} C_{\mathrm{opx}}+Y_{\mathrm{chr}} C_{\mathrm{chr}}+Y_{\mathrm{fpr}} C_{\mathrm{fpr}}+Y_{\mathrm{ph}} C_{\mathrm{ph}}$

Or,

$$
\begin{aligned}
C_{\text {rock }}= & \left(Y_{\mathrm{opx}}+Y_{\mathrm{chr}} C_{\mathrm{chr}} / C_{\mathrm{opx}}+Y_{\mathrm{fpr}} C_{\mathrm{fpr}} / C_{\mathrm{opx}}\right. \\
& \left.+Y_{\mathrm{ph}} C_{\mathrm{ph}} / C_{\mathrm{opx}}\right) C_{\mathrm{opx}} .
\end{aligned}
$$

Therefore, using Equations 1 and $2 \mathrm{~b}$, an apparent partition coefficient $D_{\text {opx }}^{\prime}\left(=C_{\text {opx }} / C_{\mathrm{L}}\right)$, can be obtained. This coefficient takes into account the effects of the trapped melt proportions and postcumulus equilibration, and can be used to discuss the composition of the parental melt:

$$
\begin{aligned}
D_{\mathrm{opx}}^{\prime}= & \left(\phi+X_{\mathrm{chr}} \times D_{\mathrm{chr} / \mathrm{melt}}+X_{\mathrm{opx}} \times D_{\mathrm{opx} / \mathrm{melt}}\right) / \\
& \left(Y_{\mathrm{opx}}+Y_{\mathrm{chr}} C_{\mathrm{chr}} / C_{\mathrm{opx}}+Y_{\mathrm{fpr}} C_{\mathrm{fpr}} / C_{\mathrm{opx}}\right. \\
& \left.+Y_{\mathrm{ph}} C_{\mathrm{ph}} / C_{\mathrm{opx}}\right) .
\end{aligned}
$$

To calculate these apparent partition coefficients, a series of parameters need to be estimated or hypothesized:

The proportions of the cumulus phases at the time of melt entrapment.

Orthopyroxene is by far the main cumulus phase. For calculation purposes, we have neglected the involvement of chromite because it displays low REEs contents, and a couple percent of this phase has virtually no effect on the budget of REEs, $\mathrm{Zr}$, and Hf.

\footnotetext{
The equilibrium partition coefficients between orthopyroxene and melt.
} 


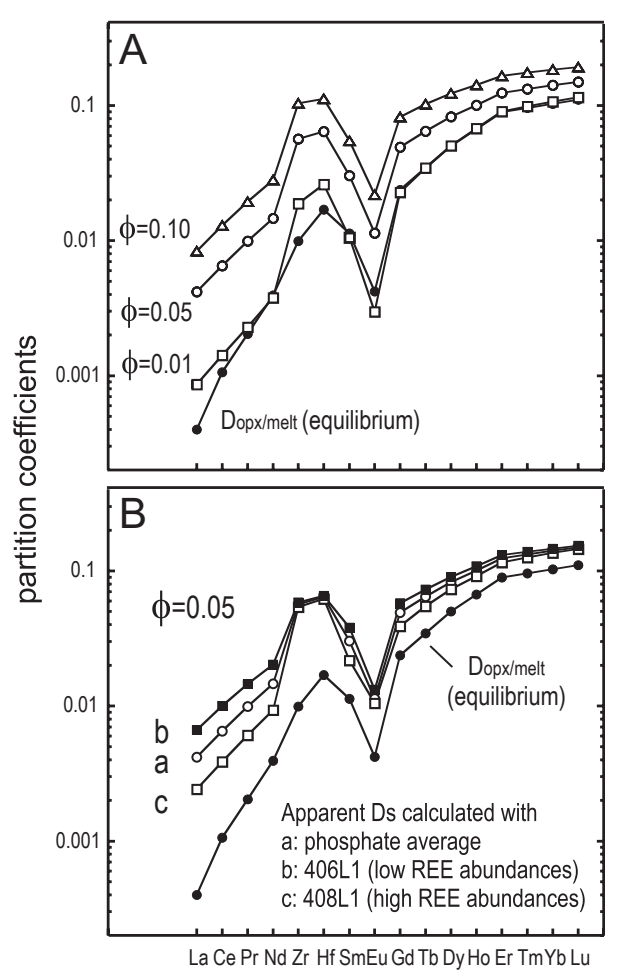

Fig. 5. A) Apparent partition coefficients for ALH 84001 calculated for various proportions of trapped melt $(1 \%, 5 \%$, $10 \%$ ) and the average phosphate composition. B) Apparent partition coefficients for ALH 84001 calculated for $5 \%$ of trapped melt and various phosphate compositions.

The partition coefficients for REE between orthopyroxene and melt have been repeatedly measured during the last 12 years, and these values are today fairly well known for a basaltic system. We have used a set of values derived from the experiments of Schwandt and McKay (1998), which are in agreement with more recent experiments performed by Green et al. (2000), Klemme et al. (2006), Adam and Green (2006), and data obtained from phenocrysts in lavas (e.g., Norman et al. 2005). Because the behavior of $\mathrm{Eu}$ is strongly dependent of the oxygen fugacity of the system, our calculations are less certain for this element. We have selected the partition coefficients of $\mathrm{Zr}$ and $\mathrm{Hf}$ obtained by Adam and Green (2006), because they are similar to the values obtained from phenocrysts in lavas (e.g., Norman et al. 2005).

Using the proportions of phases that we have calculated above from the bulk rock composition (Table 3), and the average compositions of the phases, the apparent partition coefficients between the average orthopyroxene and the parental melt have been calculated for different proportions of trapped melt (Table 5 and Fig. 7A). These partition coefficients are strongly dependent of the amount of trapped melt that crystallized in the rock. In the case of a very low

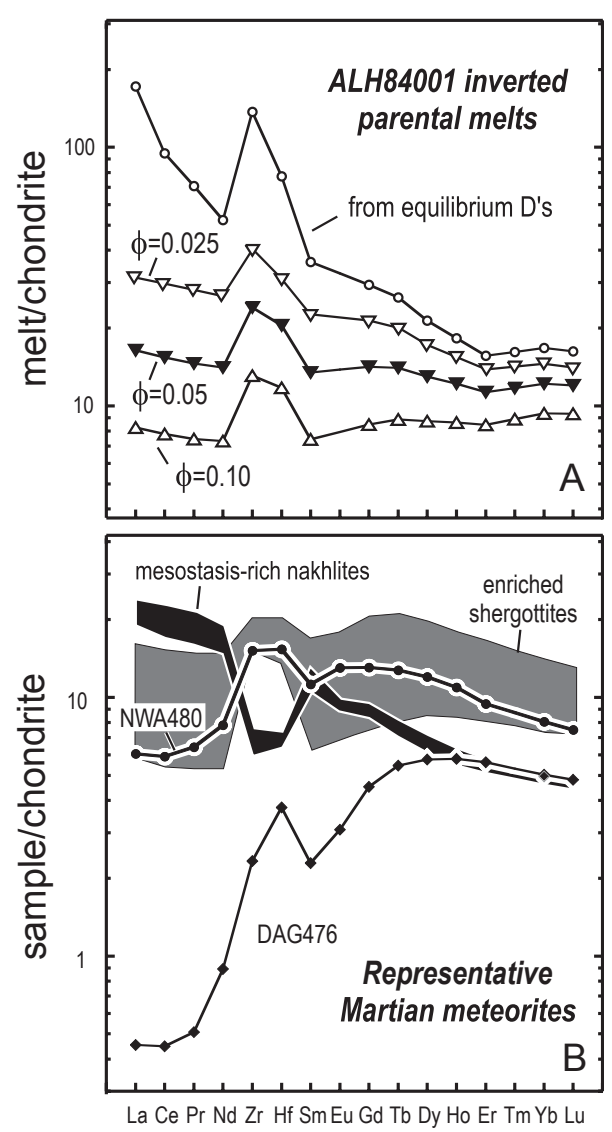

Fig. 6. A) Trace element patterns of the various parental melts calculated for ALH 84001 (see the text for more details). B) Trace element patterns of representative Martian meteorites (data from Barrat et al. [2001, 2002a, 2002b], Jambon et al. [2002], and Sautter et al. [2002]).

amount of trapped melt $(\phi=0.01$ or $1 \mathrm{wt} \%)$, the equilibrium and the apparent partition coefficients are very similar. The situation is different for slightly higher $\phi$-values. For example, the apparent partition coefficients for $\mathrm{La}, \mathrm{Zr}$, or $\mathrm{Yb}$ are respectively $10 \times, 5.7 \times$, and $1.4 \times$ the equilibrium values for $\phi=0.05$, and demonstrate that the effect of trapped melt is significant and must be taken into account for the estimation of the REE features of the ALH 84001 parental melt. In addition to the trapped melt fraction, the proportion of phosphate and its average composition are important parameters in the calculations. These effects have been illustrated in Fig. 7B using the phosphate fractions with the lowest (406L1), and with the highest REE concentrations (408L1) for $5 \%$ of trapped melt. Although the results are significantly different especially for the light REEs, the shapes of the patterns are similar to the results calculated with the phosphate average in both cases. Therefore, the uncertainties on the proportions and on the REE concentrations of the average phosphate have no real impact on the 


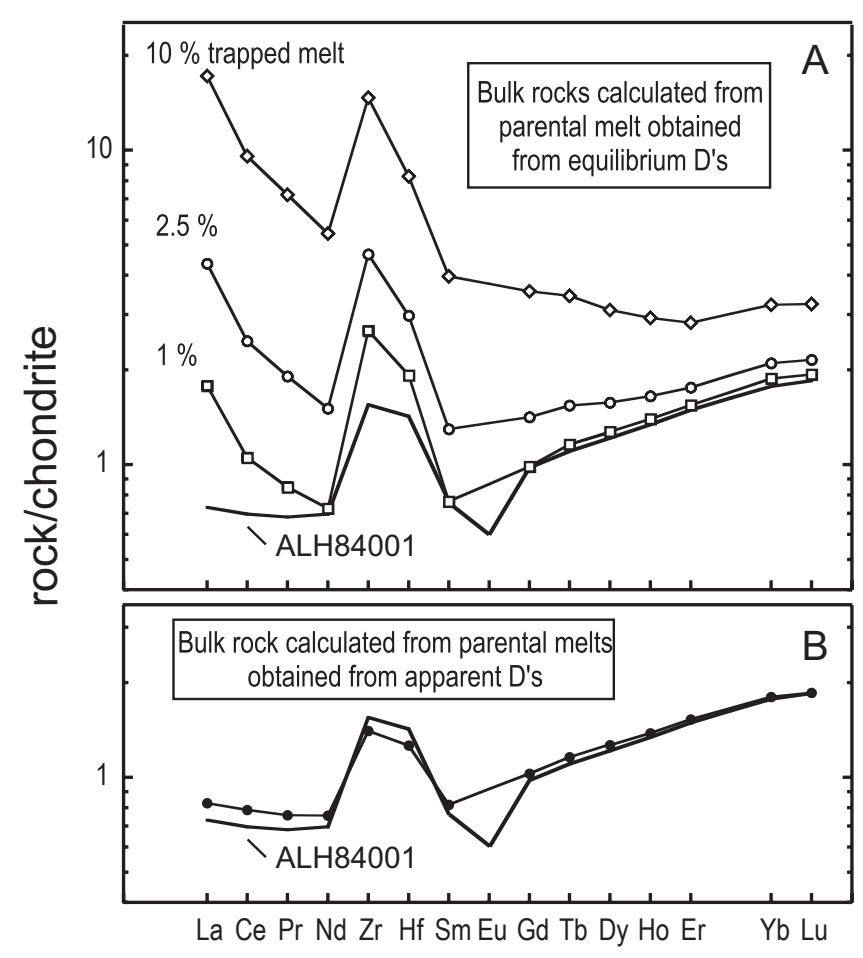

Fig. 7. Trace element patterns of the bulk rock calculated using various amounts of melt in equilibrium with the orthopyroxene (A) or using various amounts of trapped melt estimated from apparent partition coefficients (B). The observed bulk composition of ALH 84001 (this study) is shown for comparison.

conclusions we will draw on the composition of the ALH 84001 parental melt.

The proportion of trapped melt is difficult to assess, but can be estimated from the amount of interstitial phases contained by ALH 84001 (Mittlefehldt 1994). Assuming a basaltic parental melt containing about $10 \mathrm{wt} \% \mathrm{Al}_{2} \mathrm{O}_{3}$ and able to crystallize about $45 \%$ of its mass in feldspars, a $\phi$-value close to $2.5 \%$ can be deduced from our bulk average of ALH 84001. Assuming a less aluminous parental melt and able to crystallize about $25 \%$ of its mass in feldspars, a $\phi$-value close to $5 \%$ is obtained. From these assumptions, we can reasonably propose that the amount of interstitial melt in ALH 84001 was certainly much lower than $10 \%$, probably in the range $2.5-5 \%$ in agreement with previous estimates (Mittlefehldt 1994; Warren and Kallemeyn 1996).

The trace element abundances of the ALH 84001 parental melt have been calculated for some relevant $\phi$ values (Fig. 5; Table 6). The patterns obtained for $\phi$ $=2.5 \%$ and $5 \%$ are both moderately light REE enriched $\left(\mathrm{La}_{n} \mathrm{Sm}_{n}=1.2-1.5\right)$, with $\mathrm{Yb}$ abundances about $12-15 \times$ CI. The pattern obtained for $10 \mathrm{wt} \%$ of trapped melt (chosen as a limiting value) is similar
$\left(\mathrm{La}_{n} \mathrm{Sm}_{n}=1.1\right)$ with marginally lower REE abundances $(\mathrm{Yb}$ close to $9.5 \times \mathrm{CI})$. Although the proportion of trapped melt cannot be more accurately constrained, these calculations provide a reasonable picture of some relevant trace element abundances or ratios. Moreover, notice that our estimates based from the apparent partition coefficients are much less light REE enriched than the parental melt estimated from the equilibrium partition coefficients (Fig. 5), and account for the concentrations of the bulk rock (Fig. 6). Interestingly, the three calculated patterns display the same high $\mathrm{Zr}$ and $\mathrm{Hf}$ abundances with $\mathrm{Zr}_{n} / \mathrm{Sm}_{n}$ and $\mathrm{Hf}_{n} / \mathrm{Sm}_{n}$ ratios close, respectively, to 1.7 and 1.4. This result is at odds with the conclusion made by Mittlefehldt et al. (1995) who suggested that the parental melt of ALH 84001 displayed subchondritic $\mathrm{Hf} / \mathrm{Sm}$ ratios. This conclusion was based on the observation that the La abundances and the $\mathrm{Hf} / \mathrm{Sm}$ ratios measured on a series of small chips are negatively correlated. As the measured contents of La increases (assumed to reflect increasing trapped melt content), the $\mathrm{Hf} / \mathrm{Sm}$ ratio generally decreases, indicating the trapped melt has $\mathrm{Hf}_{n} / \mathrm{Sm}_{n}<0.85$. We do not follow this line of reasoning. This trend can be more likely explained by the presence in the samples of inhomogeneously distributed phosphates, which are LREE-rich and display very low $\mathrm{Hf}_{n} / \mathrm{Sm}_{n}$ ratios $(=0.05-0.12$, this study).

\section{Pinpointing the ALH 84001 Parental Melt}

Although our knowledge of the Martian lavas is still largely fragmentary, a comparison between the parental melts deduced from our approach and the Martian meteorites could be informative. The trace element patterns of the ALH 84001 inverted parental melts and the nakhlites are different. The latter are much more light REE enriched and their patterns exhibit characteristic $\mathrm{Zr}$ and $\mathrm{Hf}$ negative anomalies. Instead, the inferred ALH 84001 parental melts bear some resemblance to shergottites and exhibit the same $\mathrm{Hf} / \mathrm{Sm}$ ratios. More precisely, the calculated trace element patterns are strikingly similar to those of the enriched basaltic shergottites (e.g., Shergotty, Zagami, or Los Angeles).

Super-chondritic $\mathrm{Hf} / \mathrm{Sm}$ and $\mathrm{Zr} / \mathrm{Hf}$ ratios are not a trivial feature of the parental melt of ALH 84001. Hf, $\mathrm{Zr}$, and $\mathrm{Sm}$ are all incompatible elements in orthopyroxene, and consequently their ratios in basalts are unaffected by fractional crystallization. Among all the basaltic melts analyzed so far from Earth (e.g., the Georoc database [http://georoc.mpch-mainz.gwdg. de/georoc/]), from the Moon (e.g., Neal 2001), from some asteroidal bodies (e.g., Mittlefehldt and Lindstrom 1990, 2003; Yamaguchi et al. 2002; Barrat et al. 2003, 
2007) and from Mars (Meyer 2009), shergottites are at present the only basaltic lithologies that exhibit high $\mathrm{Hf} / \mathrm{Sm}$ and $\mathrm{Zr} / \mathrm{Sm}$ ratios. These high ratios could be the fingerprint of ilmenite or majorite in the Martian mantle (e.g., Bouvier et al. 2009; Shirai and Ebihara 2009). The high $\mathrm{Zr} / \mathrm{Sm}$ and $\mathrm{Hf} / \mathrm{Sm}$ ratios calculated for the parental melt of ALH 84001 are a strong indication of its shergottitic affinity.

Although it is beyond the scope of this discussion to review all the isotopic data obtained on Martian meteorites, further arguments in favor of a link between ALH 84001 and shergottites are provided by geochronological studies. Briefly, $\varepsilon^{142} \mathrm{Nd}$ and $\varepsilon^{182} \mathrm{~W}$ values have been reported previously for various Martian meteorites including ALH 84001 (e.g., Foley et al. 2005; Wadhwa and Borg 2006; Debaille, personal communication). These isotopic compositions allow a sharp separation of the shergottites from the nakhlites. Interestingly, the $\varepsilon^{142} \mathrm{Nd}$ and $\varepsilon^{182} \mathrm{~W}$ values determined for ALH 84001 are in the range of the shergottitic compositions. Moreover, the ${ }^{176} \mathrm{Lu} /{ }^{177} \mathrm{Hf}$ (Righter et al. 2009a, 2009b), and ${ }^{238} \mathrm{U} /{ }^{204} \mathrm{~Pb}$ ratios (Bouvier et al. 2009) for the modeled sources for the enriched shergottites and ALH 84001 are very similar. Unfortunately, the $\mathrm{Rb}-\mathrm{Sr}$ and $\mathrm{Sm}-\mathrm{Nd}$ isotope systematics do not allow this kind of comparison for numerous reasons, including the fact that $\mathrm{ALH} 84001$ is a Rb- and Sr-poor system with an intricate history involving deposition of carbonates. In the case of $\mathrm{Sm}-\mathrm{Nd}$, the results may be biased by the phosphate phases that dominate the rock budget for these elements. Consequently, neither the crystallization age, nor the initial $\left({ }^{87} \mathrm{Sr} /{ }^{86} \mathrm{Sr}\right)_{0}$ and $\left({ }^{143} \mathrm{Nd} /{ }^{144} \mathrm{Nd}\right)_{0}$ ratios have yet been deduced with sufficient accuracy from these isotopic systems (Nyquist et al. 1995; Righter et al. 2009b). Finally, Bouvier et al. (2005, 2009) have recently obtained well-defined $\mathrm{Pb}-\mathrm{Pb}$ isochrones that point to crystallization ages of $>4 \mathrm{Ga}$ for shergottites. Such $\mathrm{Pb}-\mathrm{Pb}$ systematics suggest that enriched, intermediate shergottites and ALH 84001 could be contemporary. This issue is vigorously disputed and some workers maintain much younger crystallization ages $(<500 \mathrm{Ma})$ for the shergottites (e.g., Walton et al. 2008; Nyquist et al. 2009).

While ALH 84001 formed from a melt that undeniably shared some trace elements and isotopic features with the enriched shergottites, there are several reasons why none of the known shergottites from this group can be easily linked directly to it:

- First, the pyroxenes contained by all the enriched basaltic shergottites are pigeonite and augite, not orthopyroxene as in ALH 84001. Moreover, these shergottites display Ti-magnetite but not chromite. This observation is strengthened by experimental work undertaken on Shergotty and Zagami (Stolper and McSween 1979; McCoy and Lofgren 1999; Dann et al. 2001). On the other hand, other shergottites contain both orthopyroxene and chromite such as some of the olivine-phyric shergottites (e.g., Elephant Moraine 79001A [McSween and Jarosewich 1983], Dar al Gani 476 [Zipfel et al. 2000], Yamato-980459 [Greshake et al. 2004], Larkman Nunatak 06319 [Basu Sarbadhikari et al. 2009]), and possibly the basaltic shergottite Northwest Africa 480 (Barrat et al. 2002a). Thus, petrographic constraints do not preclude the derivation of a cumulate like ALH 84001 from a shergottitic precursor.

- As pointed out above, the ALH 84001 parental melt displayed Ni concentrations much lower than all the shergottites analyzed so far, including Los Angeles which is the most evolved one described at present. Although the difference is important, one may conceivably propose that it is the result of a different crystallization history.

\section{CONCLUSIONS}

We have performed major and trace element analyses on four chips taken from different areas of ALH 84001 totaling a mass of about $1 \mathrm{~g}$. This sampling provides a picture of the heterogeneity of this unique Martian meteorite, but more importantly, allows an estimation of the bulk rock composition which is probably more accurate than previous values derived from single chip analyses. Although the bulk phosphate REE patterns obtained from each of the studied chips display a significant range of abundances because of the involvement of two distinct phases (merrillite and apatite), the compositions of the orthopyroxene fractions are homogeneous from place to place at the scale of our sampling (about 200$250 \mathrm{mg}$ chips).

The composition of the ALH 84001 parental melt can be discussed from the present data. We confirm that the trace element abundances of the parental melt cannot be directly deduced from the orthopyroxene composition (Treiman 1996): A strongly light REE enriched melt is calculated using equilibrium partition coefficients and such a melt is inconsistent with the composition of the bulk rock. This discrepancy is best explained by the involvement of a few percents of trapped melt in the rock and by subsolidus redistribution between phases. A parental melt displaying the same REE pattern and similar $\mathrm{Hf} / \mathrm{Sm}$ and $\mathrm{Zr} / \mathrm{Sm}$ ratios as enriched shergottites are calculated if these effects are taken into account.

Despite some differences between the estimated ALH 84001 parental melt and the known shergottites, ALH 84001 appears to have formed from a melt that 
displayed strong affinities with shergottites. Because ALH 84001 is unambiguously Noachian in age (e.g., Nyquist et al. 1995; Bouvier et al. 2009; Righter et al. 2009a, 2009b), this result suggests that shergottitic melts erupted early on Mars, which has important implications for our understanding of the magmatic activity of this planet and raises numerous questions. For how many millions of years or billions of years were the shergottites generated on Mars? Are all the shergottites more than $4 \mathrm{Ga}$ old as implied by $\mathrm{Pb}-\mathrm{Pb}$ dating (Bouvier et al. 2005, 2009)? Are some shergottites much younger than $500 \mathrm{Ma}$, as indicated by $\mathrm{Ar}-\mathrm{Ar},-\mathrm{Sr}$, and $\mathrm{Sm}-\mathrm{Nd}$ systematics (e.g., Nyquist et al. 2009)? These questions are still a matter of debate.

Acknowledgments - We thank Randy Korotev for the editorial handling, Christine Floss, David Mittlefehldt and an anonymous referee for constructive comments, and Pascale Barrat for her help. We gratefully acknowledge the NASA meteorite working group for providing the ALH 84001 samples, and the Programme National de Planétologie (INSU) for financial support. This research has made use of NASA's Astrophysics Data System Abstract Service.

\section{Editorial Handling-Dr. Randy Korotev}

\section{REFERENCES}

Adam J., and Green T. 2006. Trace element partitioning between mica- and amphibole-bearing garnet lherzolite and hydrous basanitic melt: 1. Experimental results and the investigation of controls on partitioning behaviour. Contributions to Mineralogy and Petrology 152:1-17.

Barrat J. A. 2004. Determination of the parental magmas of HED cumulates: The effects of interstitial melts. Meteoritics \& Planetary Science 39:1767-1779.

Barrat J. A., Blichert-Toft J., Nesbitt R. W., and Keller F. 2001. Bulk chemistry of Saharan shergottite Dar al Gani 476. Meteoritics \& Planetary Science 36:23-29.

Barrat J. A., Gillet Ph., Sautter V., Jambon A., Javoy M., Göpel C., Keller F., Lesourd M., and Petit E. 2002a. Petrology and chemistry of the basaltic shergottite NWA 480. Meteoritics \& Planetary Science 37:487-499.

Barrat J. A., Jambon A., Bohn M., Gillet Ph., Sautter V., Göpel C., Lesourd M., and Keller F. 2002b. Petrology and chemistry of the picritic shergottite Northwest Africa 1068 (NWA 1068). Geochimica et Cosmochimica Acta 66:35053518.

Barrat J. A., Jambon A., Bohn M., Blichert-Toft J., Sautter V., Göpel C., Gillet Ph., Boudouma O., and Keller F. 2003. Petrology and geochemistry of the unbrecciatted achondrite Northwest Africa 1240 (NWA 1240): An HED parent body impact melt. Geochimica et Cosmochimica Acta 67:3959-3970.

Barrat J. A., Yamaguchi A., Greenwood A., Bohn M., Cotten J., Benoit M., and Franchi I. A. 2007. The Stannern trend eucrites: Contamination of main group eucritic magmas by crustal partial melts. Geochimica et Cosmochimica Acta 71:4108-4124.

Barrat J. A., Yamaguchi A., Benoit M., Cotten J., and Bohn M. 2008. Geochemistry of diogenites: Still more diversity in their parental melts. Meteoritics \& Planetary Science 43:1759-1775.

Bartels K. S., and Grove T. L. 1991. High pressure experiments on magnesian eucrite compositions: Constraints on magmatic processes in the eucrite parent body. Proceedings, 21st Lunar and Planetary Science Conference. pp. 351-365.

Basu Sarbadhikari A., Day J. M. D., Liu Y., Rumble D. III, and Taylor L. A. 2009. Petrogenesis of olivine-phyric shergottite Larkman Nunatak 06219: Implications for enriched components in Martian basalts. Geochimica et Cosmochimica Acta 73:2190-2214.

Beck P., Barrat J. A., Gillet Ph., Wadhwa M., Franchi I. A., Greenwood R. C., Bohn M., Cotten J., van de Moortèle B., and Reynard B. 2006. Petrography and geochemistry of the chassignite Northwest Africa 2737 (NWA 2737). Geochimica et Cosmochimica Acta 70:2127-2139.

Berkley J. L. and Boynton N. J. 1992. Minor/major element variation within and among diogenite and howardite orthopyroxenite groups. Meteoritics 27:387-394.

Boctor N. Z., Alexander C. M. O'. D., Wang J., and Hauri E. 2003. The sources of water in Martian meteorites: Clues from hydrogen isotopes. Geochimica et Cosmochimica Acta 67:3971-3989.

Bouvier A., Blichert-Toft J., Vervoort J. D., and Albarede F. 2005. The age of SNC meteorites and the antiquity of the Martian surface. Earth and Planetary Science Letters 240:221-233.

Bouvier A., Blichert-Toft J., and Albarède F. 2009. Martian meteorite chronology and the evolution of the interior of Mars. Earth and Planetary Science Letters 280:285-295.

Calvin C. and Rutherford M. 2008. The parental melt of lherzolitic shergottite ALHA77005: A study of rehomogenized melt inclusions. American Mineralogist 93:1886-1898.

Corrigan C. M., Wadhwa M., and Harvey R. P. 2004. Rare earth element measurements of multi-generational(?) carbonate in meteorite Allan Hills 84001 (abstract \#1611). 35th Lunar and Planetary Science Conference. CD-ROM.

Dann J. C., Holzheid A. H., Grove T. L., and McSween H. Y. Jr. 2001. Phase equilibria of the Shergotty meteorite: Constraints on pre-eruptive $\mathrm{H}_{2} \mathrm{O}$ contents of Martian magmas and fractional crystallization under hydrous conditions. Meteoritics \& Planetary Science 36:793-806.

Dreibus G., Burghele A., Jochum K. P., Spettel B., Wlotzka F., and Wänke H. 1994. Chemical and mineral composition of ALH 84001: A Martian orthopyroxenite (abstract). Meteoritics 29:461.

Eggins S. M., Woodhead J. D., Kinsley L. P. J., Mortimer G. E., Sylvester P., McCulloch M. T., Hergt J. M., and Handler M. R. 1997. A simple method for the precise determination of $>40$ trace elements in geological samples by ICP-MS using enriched isotope internal standardization. Chemical Geology 134:311-326.

Eiler J., Valley J. W., Graham C. M., and Fournelle J. 2002. Two populations of carbonate in ALH 84001: Geochemical evidence for discrimination and genesis. Geochimica et Cosmochimica Acta 66:1285-1303.

Evensen N. M., Hamilton P. J., and O’Nions R. K. 1978. Rare Earth abundances in chondritic meteorites. Geochimica et Cosmochimica Acta 42:1199-1212. 
Foley N. C., Wadhwa M., Borg L. E., Janney P. E., Hines R., and Grove T. L. 2005. The early differentiation history of Mars from ${ }^{182} \mathrm{~W}_{-}{ }^{142} \mathrm{Nd}$ isotope systematics in the SNC meteorites. Geochimica et Cosmochimica Acta 69:45574571.

Gleason J. D., Kring D. A., Hill D. H., and Boynton W. V. 1997. Petrography and bulk chemistry of Martian orthopyroxenite ALH 84001: Implications for the origin of secondary carbonates. Geochimica et Cosmochimica Acta 61:3503-3512.

Green T. H., Blundy J. D., Adam J., and Yaxley G. M. 2000. SIMS determination of trace element partition coefficients between garnet, clinopyroxene and hydrous basaltic liquids at 2-7.5 GPa and 1080-1200 ${ }^{\circ} \mathrm{C}$. Lithos 53:165-187.

Greenwood J. P. and McSween H. Y. 2001. Petrogenesis of Allan Hills 84001: Constraints from impact melted feldspathic and silica glasses. Meteoritics \& Planetary Science 36:43-61.

Greenwood J. P., Blake R. E., and Coath C. D. 2003. Ion microprobe measurements of ${ }^{18} \mathrm{O} /{ }^{16} \mathrm{O}$ ratios of phosphate minerals in the Martian meteorites ALH 84001 and Los Angeles. Geochimica et Cosmochimica Acta 67:2289-2298.

Greshake A., Fritz J., and Stöffler D. 2004. Petrology and shock metamorphism of the olivine-phyric shergottite Yamato 980459: Evidence for a two-stage cooling and a single-stage ejection history. Geochimica et Cosmochimica Acta 68:2359-2377.

Harvey R. P. and McSween H. Y. Jr. 1992. The parent magma of the nakhlite meteorites: Clues from melt inclusions. Earth and Planetary Science Letters 111:467-482.

Ionov D. A., Prikhodo V. S., Bodinier J. L., Sobolev A. V., and Weis D. 2005. Lithospheric mantle beneath southeastern Siberian craton: Petrology of peridotite xenoliths in basalts from Tokinsky Stavonik. Contributions to Mineralogy and Petrology 149:647-665.

Jagoutz E., Bowring S., Jotter R., and Dreibus G. 2009. New U-Th-Pb data on SNC meteorite ALHA 84001 (abstract \#1662). 40th Lunar and Planetary Science Conference. CD-ROM.

Jambon A., Barrat J. A., Sautter V., Gillet Ph., Göpel C., Javoy M., Joron J. L., and Lesourd M. 2002. The basaltic shergottite Northwest Africa 856: Petrology and geochemistry. Meteoritics \& Planetary Science 37:11471164.

Johnson M. C., Rutherford M. J., and Hess P. C. 1991. Chassigny petrogenesis: Melt compositions, intensive parameters, and water contents of Martian magmas. Geochimica et Cosmochimica Acta 55:349-366.

Klemme S., Günther D., Hametner K., Prowatke S., and Zack T. 2006. The partitioning of trace elements between ilmenite, ulvospinel, armalcolite, and silicate melts with implications for the early differentiation of the Moon. Chemical Geology 234:251-263.

Kong P., Ebihara M., and Palme H. 1999. Siderophile elements in Martian meteorites and implications for core formation in Mars. Geochimica et Cosmochimica Acta 63:1865-1875.

Kring D. A., Gleason J. D., Swindle T. D., Nishiizumi K., Caffee M. W., Hill D. H., Jull A. J. T., and Boynton W. V. 2003. Composition of the first bulk melt sample from a volcanic region of Mars: Queen Alexandra Range 94201. Meteoritics \& Planetary Science 38:1833-1848.
McCoy T. J., and Lofgren G. E. 1999. Crystallization of the Zagami shergottites: An experimental study. Earth and Planetary Science Letters 173:397-411.

McKay D. S., Gibson E. K., Thomas-Keprta K. L., Vali H., Romanek C. S., Clemett S. J., Chillier X. D. F., Maechling C. R., and Zare R. N. 1996. Search for life on Mars: Possible relic biogenic activity in Martian meteorite ALH 84001. Science 273:924-930.

McSween H. Y. Jr., and Jarosewich E. 1983. Petrogenesis of the EETA79001 meteorite: Multiple magma pulses on the shergottite parent body. Geochimica et Cosmochimica Acta 47:1501-1513.

Meyer C. 2009. The Mars meteorite compendium. http://wwwcurator.jsc.nasa.gov/antmet $/ \mathrm{mmc} /$.

Mittlefehldt D. W. 1994. ALH 84001, A cumulate orthopyroxenite member of the Martian meteorite clan. Meteoritics 29:214-221.

Mittlefehldt D. W., and Lindstrom M. M. 1990. Geochemistry and genesis of the angrites. Geochimica et Cosmochimica Acta 55:77-87.

Mittlefehldt D. W., and Lindstrom M. M. 2003. Geochemistry of eucrites: Genesis of basaltic eucrites, and $\mathrm{Hf}$ and $\mathrm{Ta}$ as petrogenetic indicators for altered Antarctic eucrites. Geochimica et Cosmochimica Acta 67:1911-1934.

Mittlefehldt D. W., Lindstrom M. M., and Gibson E. K. 1995. ALH 84001: Trace element geochemical similarities of its trapped melt component to Nakhla, Lafayette and Chassigny (abstract). 26th Lunar and Planetary Science Conference. pp. 983-984.

Neal C. R. 2001. Interior of the Moon: The presence of garnet in the primitive deep lunar mantle. Journal of Geophysical Research 106:27865-27885.

Norman M., Garcia M. O., and Pietruszka A. 2005. Traceelement distribution coefficients for pyroxenes, plagioclase, and olivine in evolved tholeiites from the 1955 eruption of Kilauea Volcano, Hawai'i and petrogenesis of the differentiated rift-zone lavas. American Mineralogist 90:888-899.

Nyquist L. E., Bansal B., Wiesmann H., and Shih C.-Y. 1995. "Martians" young and old: Zagami and ALH 84001 (abstract). 26th Lunar and Planetary Science Conference. pp. 1065-1066.

Nyquist L. E., Bogard D. D., Shih C. Y., Park J., Reese Y. D., and Irving A. J. 2009. Concordant Rb-Sr, Sm-Nd, and $\mathrm{Ar}-\mathrm{Ar}$ ages for Northwest Africa 1460: A $346 \mathrm{Ma}$ old basaltic shergottite related to "lherzolitic" shergottites. Geochimica et Cosmochimica Acta 73:4288-4309.

Papike J. J., Fowler G. W., Layne G. D., Spilde M. N., and Shearer C. K. 1994. ALH 84001 A "SNC orthopyroxenite": Insights from SIMS analysis of orthopyroxene and compositions to diogenites (abstract). 25th Lunar and Planetary Science Conference. pp. 1043-1044.

Righter M., Lapen T. J., Brandon A. D., Beard B. L., Shafer J. T., and Peslier A. H. 2009a. Lu-Hf age and isotope systematics of ALH 84001 (abstract \#2256). 40th Lunar and Planetary Science Conference. CD-ROM.

Righter M., Lapen T. J., Brandon A. D., Beard B. L., and Shafer J. T. 2009b. Lu-Hf and Sm-Nd isotope systematics of ALH 84001: Evidence for an ancient enriched mantle reservoir on Mars (abstract \#5429). 72nd Annual Meteoritical Society Meeting.

Sautter V., Barrat J. A., Jambon A., Javoy M., Lorand J. P., Gillet Ph., Joron J. L., and Lesourd M. 2002. A new Martian 
meteorite from Morocco: The nakhlite Northwest Africa 817. Earth and Planetary Science Letters 195:223-238.

Schwandt C. S., and McKay G. 1998. Rare earth element partition coefficients from enstatite/melt synthesis experiments. Geochimica et Cosmochimica Acta 62:28452848.

Shirai N., and Ebihara M. 2009. Chemical characteristics of the lherzolitic shergottite Yamato-000097: Magmatism on Mars inferred from the chemical compositions of shergottites. Polar Science 3:117-133.

Stockstill K. R., McSween H. Y., and Bodnar R. J. 2005. Melt inclusions in augite of the Nakhla Martian meteorite; Evidence for basaltic parental melt. Meteoritics \& Planetary Science 40:377-396.

Stolper E. M. 1977. Experimental petrology of eucrite meteorites. Geochimica et Cosmochimica Acta 41:587-611.

Stolper E. M., and McSween H. Y. Jr. 1979. Petrology and origin of the Shergottite meteorites. Geochimica et Cosmochimica Acta 43:1475-1498.

Terada K., Monde T., and Sano Y. 2004. Ion microprobe $\mathrm{U}-\mathrm{Th}-\mathrm{Pb}$ dating of phosphates in Martian meteorite ALH 84001. Meteoritics \& Planetary Science 38:16971703.

Treiman A. H. 1993. The parental magma of the Nakhla (SNC) achondrite, inferred from magmatic inclusions. Geochimica et Cosmochimica Acta 57:4753-4767.

Treiman A. H. 1995. A petrographic history of Martian meteorite ALH 84001: Two shocks and an ancient age. Meteoritics 30:294-302.

Treiman A. H. 1996. The perils of partition: Difficulties in retrieving magma compositions from chemically equilibrated basaltic meteorites. Geochimica et Cosmochimica Acta 60:147-155.

Treiman A. H. 1998. The history of Allan Hills 84001 revised: Multiple shock events. Meteoritics \& Planetary Science 33:753-764.
Usui T., McSween H. Y., and Floss C. 2008. Petrogenesis of olivine-phyric shergottite Yamato 980459, revisited. Geochimica et Cosmochimica Acta 72:1711-1730.

Wadhwa M., and Borg L. E. 2006. Trace element and $142 \mathrm{Nd}$ systematics in the nakhlite MIL 03346 and the orthopyroxenite ALH 84001: Implications for the Martian mantle (abstract \#2045). 37th Lunar and Planetary Science Conference. CD-ROM.

Wadhwa M., and Crozaz G. 1998. The igneous crystallization history of an ancient Martian meteorite from rare earth element microdistributions. Meteoritics \& Planetary Science 33:685-692.

Wadhwa M., McSween H. Y., and Crozaz G. 1994. Petrogenesis of shergottite meteorites inferred from minor and trace element microdistributions. Geochimica et Cosmochimica Acta 58:4213-4229.

Walton E. L., Kelley S. P., and Herd C. D. K. 2008. Isotopic and petrographic evidence for young Martian basalts. Geochimica et Cosmochimica Acta 72:5819-5837.

Warren P. H., and Kallemeyn G. W. 1996. Siderophile trace elements in ALH 84001, other SNC meteorites and eucrites: Evidence of heterogeneity, possibly time-linked, in the mantle of Mars. Meteoritics \& Planetary Science 31:97-105.

Warren P. H., Kallemeyn G. W., and Kyte F. T. 1999. Origin of planetary cores: Evidence from highly siderophile elements in Martian meteorites. Geochimica et Cosmochimica Acta 63:2105-2122.

Yamaguchi A., Clayton R. N., Mayeda T. K., Ebihara M., Oura Y., Miura Y. N., Haramura H., Misawa K., Kojima H., and Nagao K. 2002. A new source of basaltic meteorites inferred from Northwest Africa 011. Science 296:334-336.

Zipfel J., Sherer P., Spettel B., Dreibus G., and Schultz L. 2000. Petrology and chemistry of the new shergottite Dar al Gani 476. Meteoritics \& Planetary Science 35:95-106. 